\title{
قيمة الثعر العربي التاريخية ووجوه الاستفادة منها من خلال تثبيت صورة الحثمة عند النساء
}

The historical value of Arabic poetry and ways to benefit from it through fixing the image of decency among women

عمارة سعد شندول"

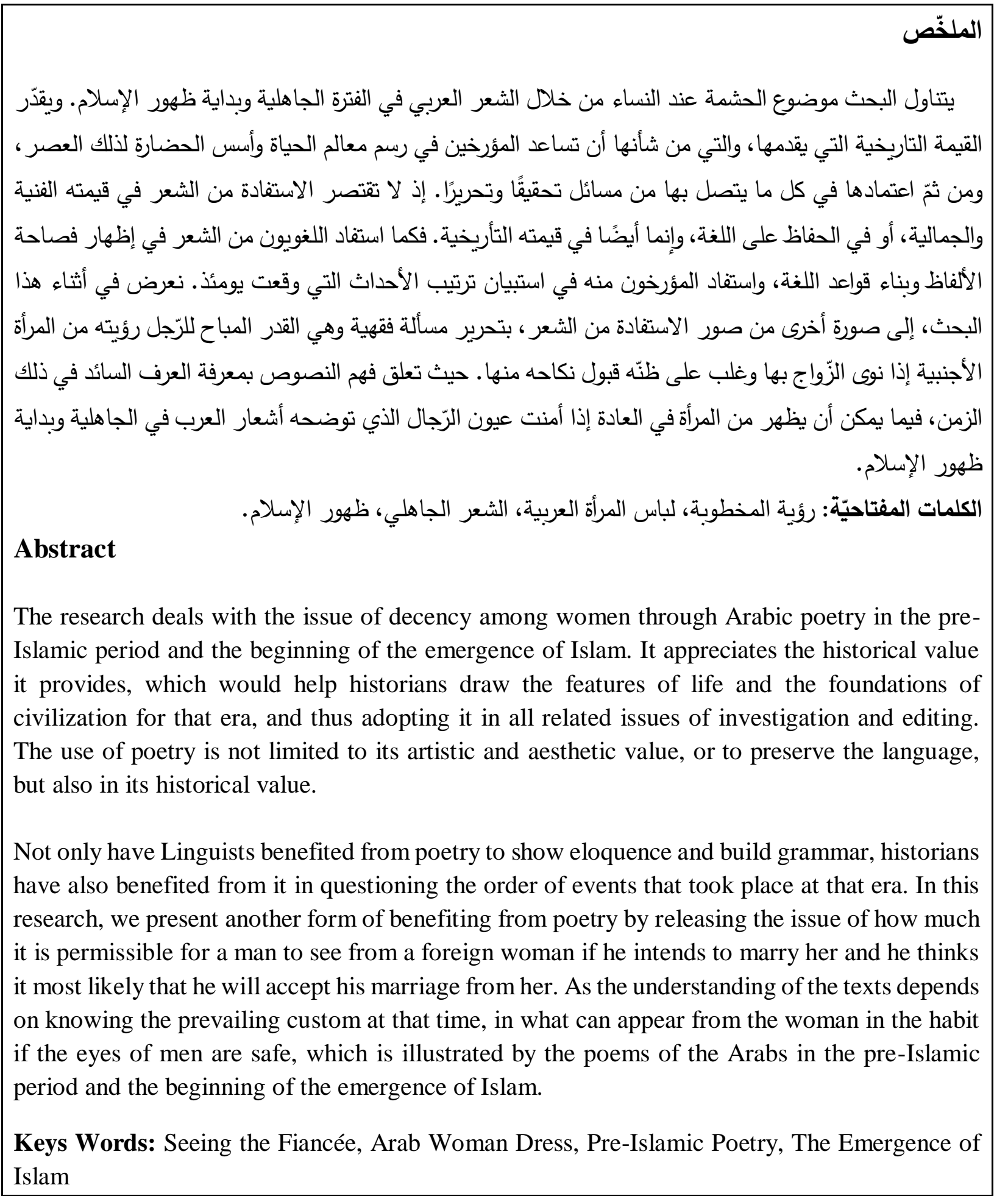

* المعهر العالي للإعلامية والملتيميديا، جامعة صفاقس، تونس، تاريخ استلام البحث 2021/02/21، تاريخ قبوله 2021/04/16 2020 


\section{المقدمة}

يمثّل الثعر العربي في الجاهلية وبدايات ظهور الإسلام، مرآة صادقة تعكس تفاصيل الحياة العربية في تلك الفترة. وديوانا يؤرخ لمجموعة من المآثر والأخلاق والأعراف والعادات ويحفظ لنا كثيرًا من اللفتات الإنسانية الرائعة. فهو مستودعُ علومهم وحافظُ آدابهم ومعدنُ أخبارهم، فضلا عما يقدمه من مزية في حفظ لسان العرب وأنسابهم وتاريخ

حروبهم •

وقد قيل:

الثعرُ يحفظ ما أودى الزمانُ به و والثعرُ أفخر ما يُنْبي عن الكرم

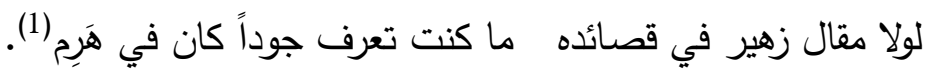

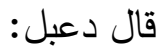

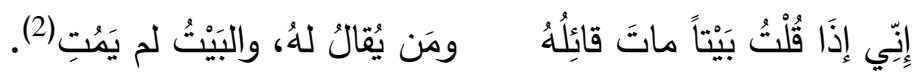

قال عمر بن الخطاب رضي الله عنه: كان الثعر علم قوم لم يكن لهم علم أصح منه. قال ابن سلام: وكان

الثعر في الجاهلية عند العرب ديوان علمهم ومنتهى حكمه به، به يأخذون وإليه يصيرون (3).

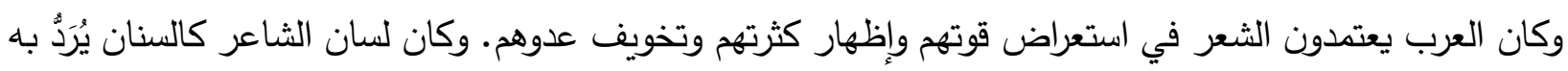

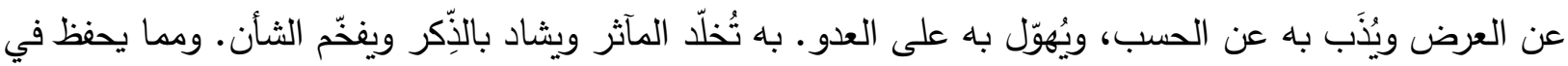

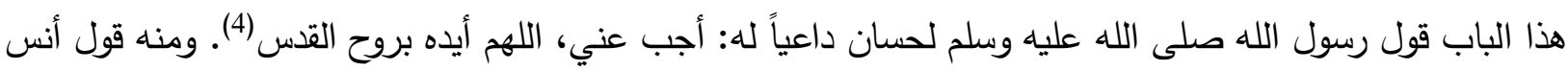
رضي الله عنه: دخل النبي صلى الله عليه وسلم مكة في عمر القضاء، وابن رواحة بين يديه، وهو يقول: خلوا بني الكفار عن سبيله اليوم نضربكم على تأويله ضرباً يزيل الهام عن مقيله ويذهل الخليل عن خليله فقال عمر : يا ابن رواحة أفي حرم الله وبين يدي رسول الله صلى الله عليه وسلم تقول هذا الثعر؟، فقال رسول الله صلى الله عليه وسلم: خل عنه يا عمر، فو الذي نفسي بيده لكلامه أشد عليهم من وقع النبل (5).

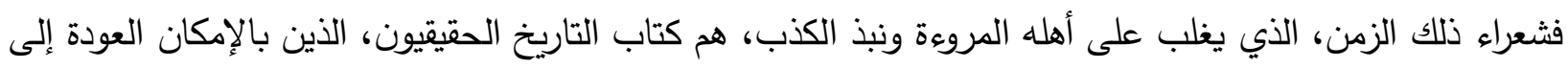
ما دونوه، للوقوف على حقائق الحياة عندهم، ومعرفة الحال والأحوال يومئذ. فقصائدهم انعكاسات ساطعة ولفتات بيّنة لما كان يحصل في زمانهم ومكانهم.

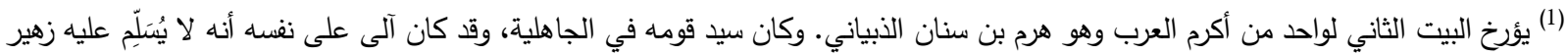

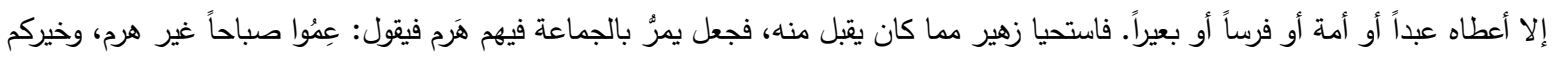

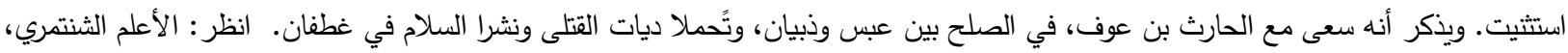

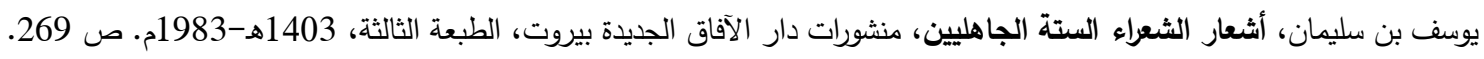
(2) الخزاعي، دعبل بن علي، شعر دعبل بن علي الخزاعي، صنعه: عبد الكريم الأشتر ، مطبوعات مجمع اللغة العربية بدمثق، الطبعة الثانية، 1403هـ-1983م، ص 195

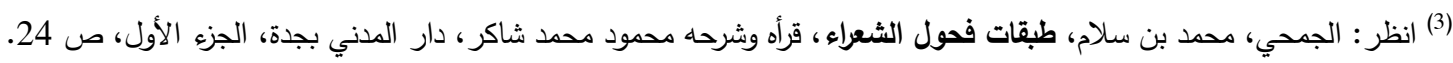

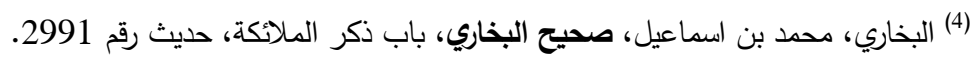

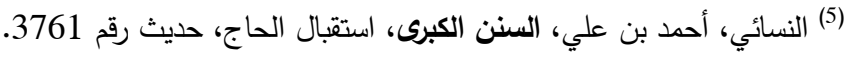


لذلك تتعدى قيمة الثعر في الفترة الجاهلية وبداية ظهور الإسلام، كونه حفظ اللغة العربية من العجمة، إلى كونه حفظ جزءًا كبيرًا من نظام الحياة الذي من شأنه أن يكون له الأثر المهم في فهم مسيرة الأمة المشحونة بالتحديات والألهات الأحداث

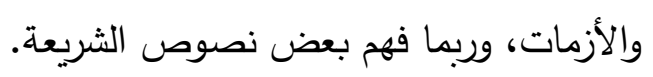
ويبدو أن الدراسات التاريخية والفقهية ستبقى ناقصة وغير وافية في بعض المسائل، بدون الاستعانة بما كتبه الثعراء زمن نزول الرسالة. وسنحاول في هذا البحث استجلاء القيمة التأريخية للشعر العربي في تلك الفترة، واستبيان نواحي الاستفادة منه، من خلال النظر في صفاء صورة الحشمة عند النساء العربيات الحرائر ، وما تحمله تلك الثهادة التاريخية من قيمة في تحرير بعض مسائل الفقه الإسلامي.

\section{أهمية الدراسة}

تتمثل أهمية البحث في كونه يعرض مسألة من المسائل التي يؤرخ لها الثعر العربي في الجاهلية وبداية ظهور الإسلام، وهي الحشمة عند النساء الحرائر • وهي مسألة قد تذهب أذهان البعض إلى الغفلة عنها، ذلك أن شعراء

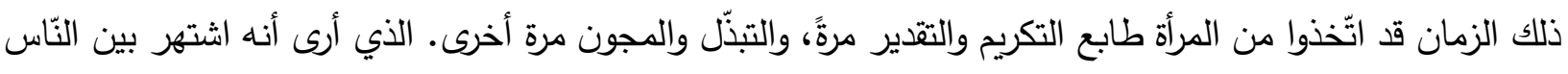
هو الثاني، حيث تم التركيز على الصور البذيئة للمرأة التي اعتمدها بعض الثعراء من أصحاب الهوى في ذلك العهد، وذلك بديلاً عن الصورة العفيفة المكرمة للمرأة. حتى انكفأ الغطاء على الحقائق التي كان يعيشها أصحاب المروءة والفطرة، من عفة وحشمة وحياء، وهم غالباً عرب ذلك الزمان وفي كل قبائلهم. فقد كانوا يعدّون المرأة ذروة شرفهر

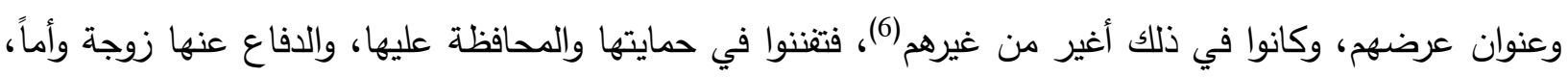
وابنة وأختاً، وقريبة وجارة، حتى يظل شرفهم قائمًا سليماً من الدنس، ويبقى عرضهه بعيداً من أن يمس. ولم يكن شيء يثير القوم كالاعتداء على نسائهم أو المساس بهن، ولذلك كانوا يتجشمون في الدفاع عنهن كل صعب، ولا يضنون

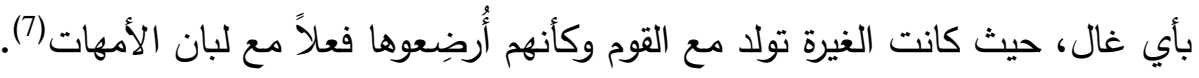
ثم جاء الإسلام فتبت ذلك دينًا يدين به المسلمون جميعًا، وصارت الحشمة في النّساء والمروءة في الرجال زينة الإسلام وعنوانه.

\section{أهداف الاراسة}

\section{تهدف الدراسة إلى تحقيق الأهداف التالية:}

- - إبراز القيمة التاريخية للشعر العربي في الجاهلية وبداية ظهور الإسلام. تهائ. - - بيان أثر الثعر في دراسة المسائل التاريخية المتعلقة بمرحلة الجاهلية وبداية ظهور الإسلام.

(6) الألوسي، محمد شكري، بلوغ الأرب في معرفة أحوال العرب، تحقيق: محمد بهجة الأثري، دار الكتاب المصري، باب ذكر الملائكة، الجزء الأول، ص

(7) صيام، محمد الثيخ محمود، المتقدات والقيم في الثعر الجاهلي، رسالة دكتوراه في الآداب، كلية اللغة العربية، جامعة أم القرى، مكة المكرمة، 


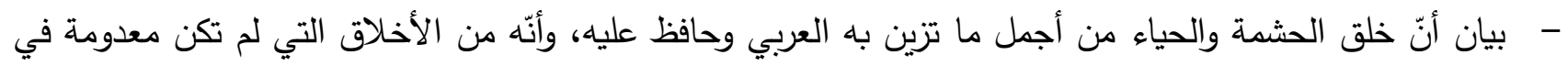

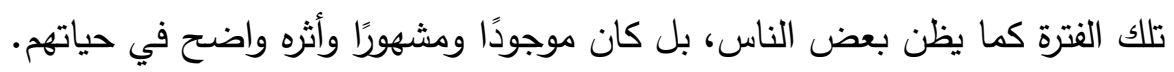

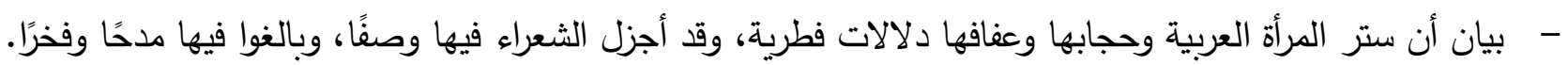

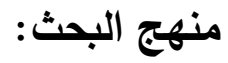

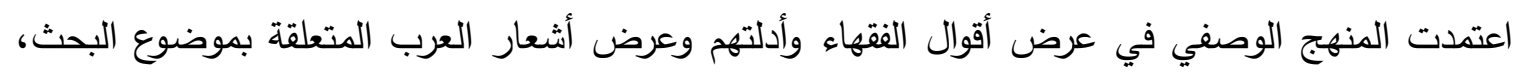
واستخدمت المنهج المقارن لمقارنة الأدلة والأقوال وبيان القوي من الأدلة، والراجح من الأقوال.

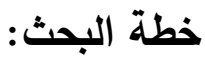

اقتضت دراسة الموضوع تقسيم البحث إلى مقدمة، وثلاثة مباحث رئيسية وخاتمة:

المبحث الأوّل: معنى الحشمة وما يتعلق بها.

المبحث الثاني: لباس المرأة العربية العفيفة وصفاتها في الجاهلية وبداية ظهور الإسلام.

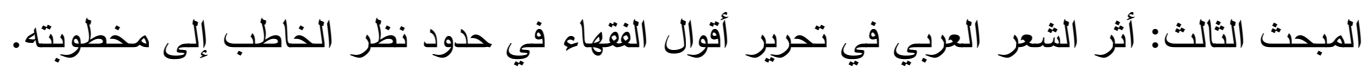
الخاتمة: وتضمنت أهم النتائج.

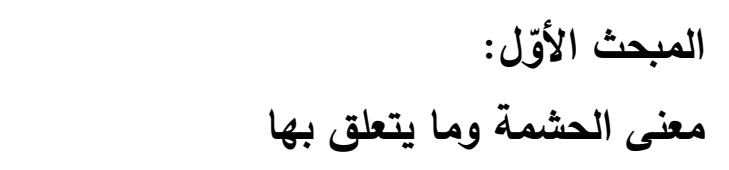
الحشمة، بكسر الحاء، من حشم، وهي على معان:

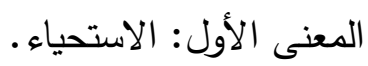

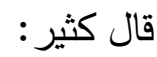

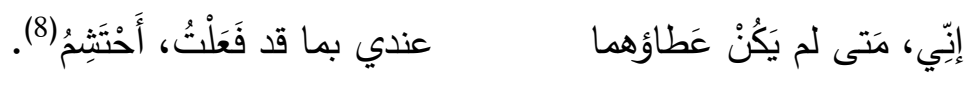
قََالَ عَنْتْرَة:

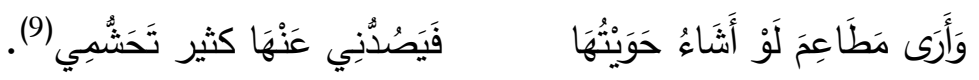
قال المتنبي:

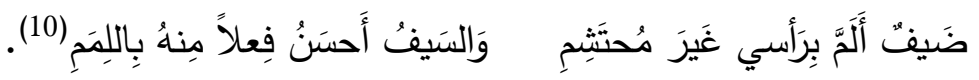

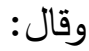

إذا ما استحين الماء يعرض نفسه كرعن بسبت في إناء من الورد(11).

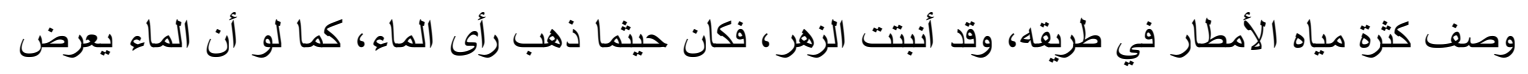

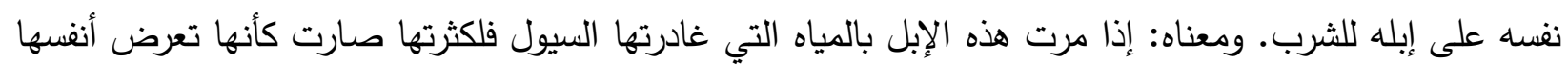
الراب، (بن جني، عثمان، الفسر - شرح ابن جني الكبير على ديوان المتبي، حققه وقدم له: رضا رجب، دار سعد الدين، الطعة الأولى، 2004م، الجزء

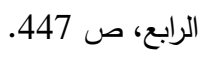

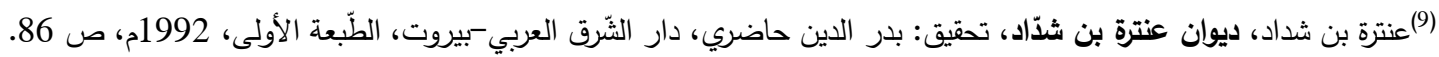

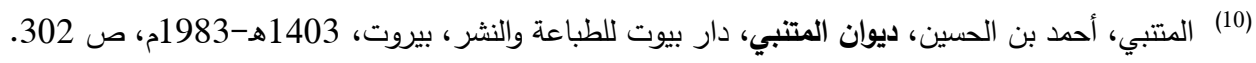

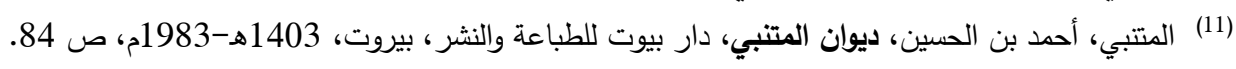


على الإبل فتشرب منها كأنها مستحية منها لكثرة عرضها نفوسها عليها وإن كان لا عرض هناك ولا استحياء في الحقيقة. وأراد الثاعر بالسبت، مشافر الإبل للينها ونقائها. والسبت جلود تدبغ بالقرظ، وهو نوع من الثجر ، ومنه قول طرفة:

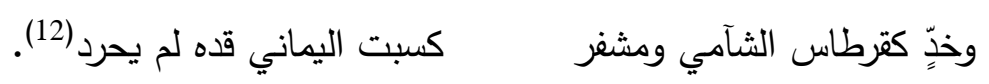

وكرعن شربن وأصله من ادخال أكارع الثاربة في الماء للشرب. وجعل الموضع المتضمن للماء لكثرة الزهر فيه كأنه

$$
\text { قالناء من ورد. }
$$

حبذا حشمة الصديق إذا ما حجزت بينه وبين العقوقِ(13).

وتأتي الحشمة بمعنى الانقباض، وهو الثاني:

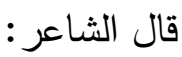

أخاف تكرار قولي: كل فأحشمه والصمت ينزله مني على بخل(14).

وتأتي بمعنى الخجل، وهو الثالث.

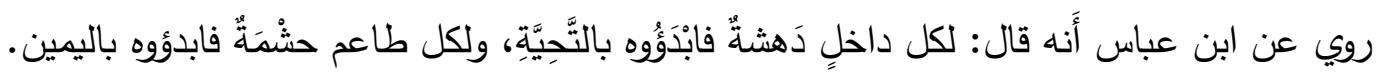

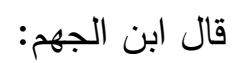

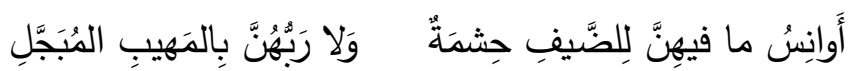

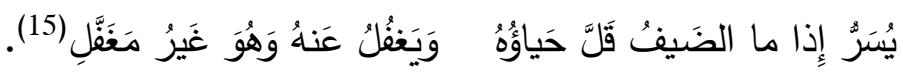

قال أبو نواس:

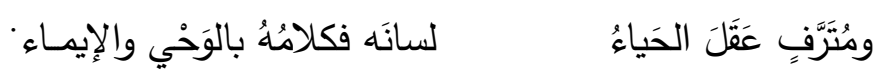

وتأتي الحشمة بمعنى الغضب، وهو الرابع.

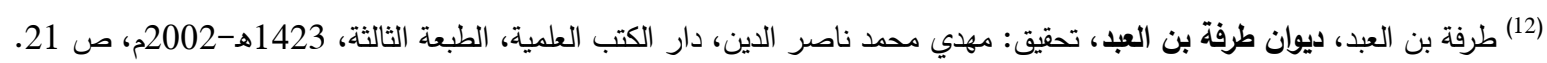
(13) الحصري القيرواني (ت 453 هـ)، إبراهيم بن علي، جمع الجواهر في الملح والنوادر (ذيل زهر الآداب)، تحقيق: علي محمد البجاوي الطبعة الثانية،

1407 هـ، دار الجيل، ص 29.

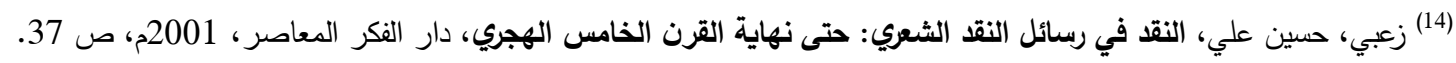

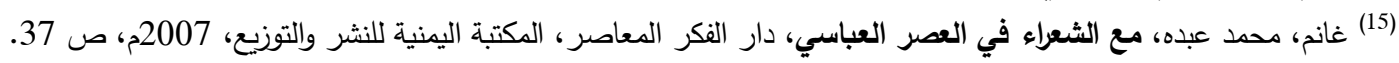


قال أبو يعقوب الخريمي، الثاعر: دخلت حمامًا في درب الثلج، فإذا بسوار بن عبد الله، قاضي البصرة لأبي جعفر المنصور، في الحمام، في البيت الداخل، مستلقيًا، وعليه المئزر، فجلست بقربه، فسكت ساعة ثم قال لي: قد أحشمتي لئي يا رجل! إما أن تخرج أو أخرج. فقلت: جئت أسألك عن مسألة. فقال: ليس هذا موضع المسائل. قلت: إنها من مسائل الحمام، فضحك وقال: هاتها، فقلت: من الذي يقول:

سلبت عظامي لحمها، فتركتها عول عواري مما نالها تتكسر (16).

شاهد الرواية، قوله: أحشمتني، أي أغضبتتي. وتأتي الحشمة بمعنى القليل الذي لا يكفي، وهو الخامس.

قال الثاعر :

لعمرك إن قرص أبى خبيب بطئ النضج محشوم الأكيل(17).

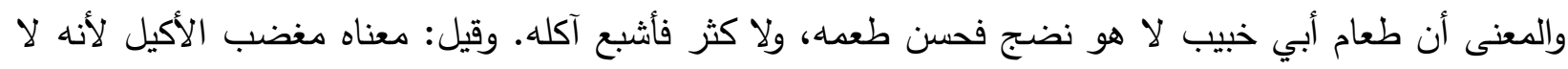
يرضيه. وتأتي بمعنى الفحش والخطيئة والفسق، وهو السادس.

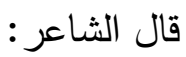

ولا تك ممن يتهمهم بحشمة فليس لهم بين الرجال محاشم(18).

والحُشمة، بضم الحاء، والحَشَم، خاصة الرجل وخَدَمه.

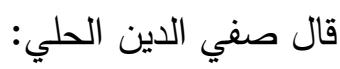
لا عيب فيهم سوى أن النزيل بهم يسلو عن الأهل والأوطان والحشم(19). والبيت في المدح لا الذم، يريد تجاوز القوم الحدَّ في الكرم وحسن الضيافة حدا يسلو النزيل بهم عن الأهل والوطن والحشم. ومن الدعائم التي قامت عليها الأخلاق العربية، الحشمة التي ميزت نساء العرب. حتى كانت صيانة النساء عنوان الرجولة وبدونها لا رجولة. قال الثاعر :

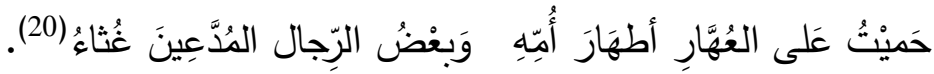

$$
\text { (16) السراج، جعفر بن أحمد (المتوفى: 500هـ)، مصارع العشاق، دار صادر ، بيروت، الجزء الثاني، ص } 6 .
$$

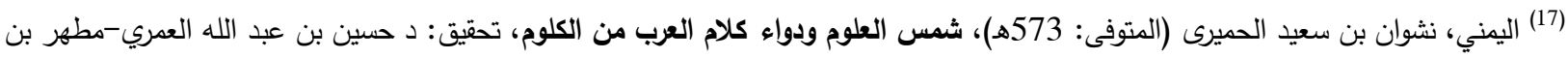

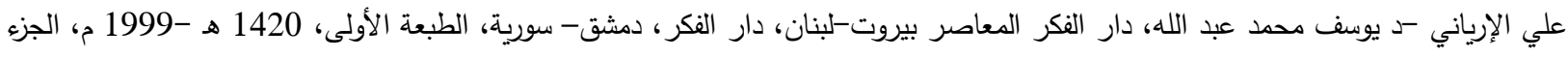

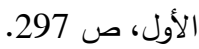
(18) الحموي، تقي الدين أبو بكر بن حجة (المتوفى: 837هـ)، خزانة الأدب وغاية الأرب، تحقيق: عصام شقيو، دار ومكتبة الهلال-بيروت، دار البحار -

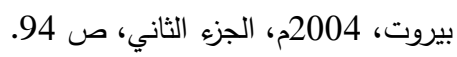
(19) المرجع السابق، الجزء الثاني، ص الزي، صن 399.

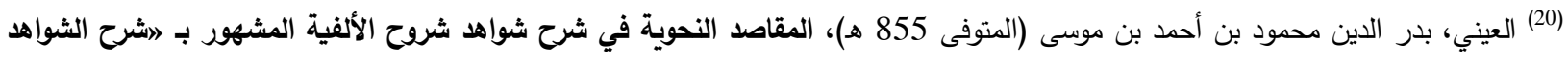

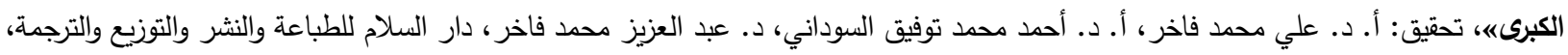

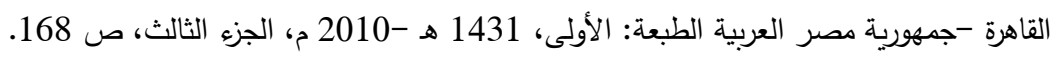


وتساوى التعدي على العرض بالحرب وطلب التقتل. وكانت مما يفتخر به وحُقَّ. وفي المثل: كُلُّ شَيء مَهَهُه، مَا خَلاً

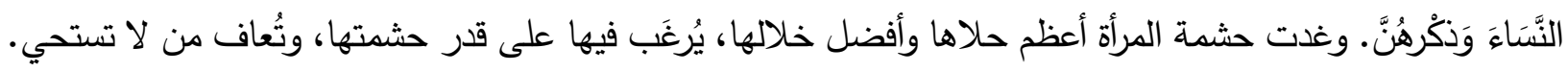

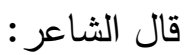

\title{
يَعافُ وِصالَ ذاتِ البَذلِ قَلبي
}

وللحشمة، الممدوحة عند النساء، مظاهر شتى، منها التصون في الكلام فلا يسمع منها غير العف من القول. قال الثاعر:

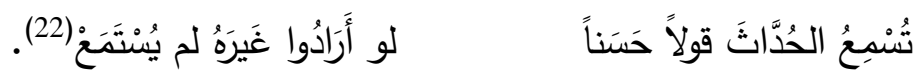

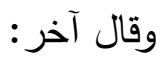

ويخالها المرح السفيه تحبه ونوالها غير الحديث بعيد(23).

وقد تضرب حشمتها حجابًا فلا يصل إليها أحد، ولا يجرؤ أحد أن يكلمها ولا يسمع لها صوتًا.

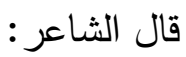

\author{
منعمة لا يستطاع كلامها على بابها من أن تزار رقيب \\ إذا غاب عنها البعل لم تفش سره وترضى إياب البعل حين يؤوب(24).
}

وقد تبلغ الحشمة حدا تمتنع فيه المرأة عن الضحك وتكتفي بالابتسام وهو أبلغ.

قال الثاعر :

نواعم ما يضحكن إلا تبسمًا إلى اللهو قد مالت بهن السوالف(25).

وقد تظهر حشمتها في لباسها، وهو ما سنعرض له في المبحث الثاني. والمرأة في لباسها بين الحجاب والسفور .

فإذا كثفت عن وجهها أو شيء من شعرها كانت سافرة، وإذا كثفت عن يديها كانت حاسرة وإذا كثفت عن شيء خلاف ذلك كانت عارية، وإذا سقط عنها كل شيء فبان ما خفي كانت متجردة. وإذا أظهرت شيئا من بدنها أو زينتها قصدًا أمام الأجانب صارت متبرّجة. فخص التبرّج بإبداء الوجه أو غيره من البدن أو من الزينة المكتسبة بغاية كثفه، فيلحق به التكشف، والتهتك، والتذلل بالنظرة والخضوع بالقول والملاينة بالكلام، والميلان بالجسد، وتتثي المرأة في

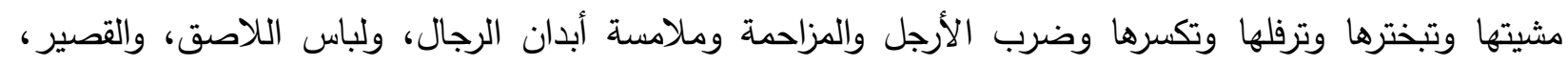
والضيق، والثفاف الواصف لبشرتها أو ما خفي من الثياب تحت وضربت العباءة.

(21) السليك بن عمير بن يثربي بن سنان السعدي التميمي (ت 17 ق.هـ)، السليك بن السلكة اخباره وشعره، دراسة وتحقيق: حميد آدم ثوينى -كامل

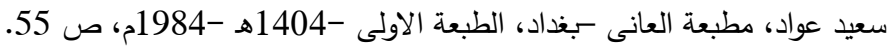

(22) سويد بن أبي كاهل اليثكري، ديوان سويد بن أبي كاهل اليثكري، جمع وتحقيق: شاكر العاشور، مراجعة: محمد جبار المعيبد، ساعدت وزارة الإعلام

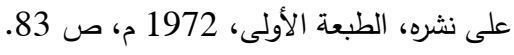

(23) الزركلي، خير الدين، الأعلام، دار العلم للملايين، بيروت-لبنان، الطبعة 15، 2002م، الجزء الخامس، ص 227.

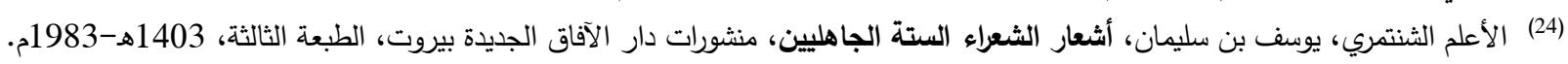




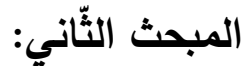

\section{لباس المرأة العربية العفيفة وصفاتها في الجاهلية وبداية ظهور الإسلام}

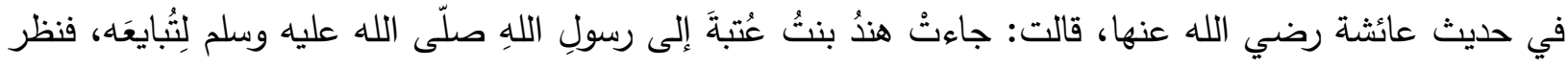

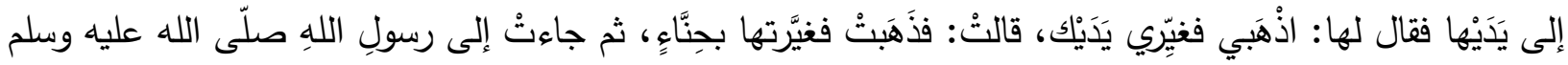

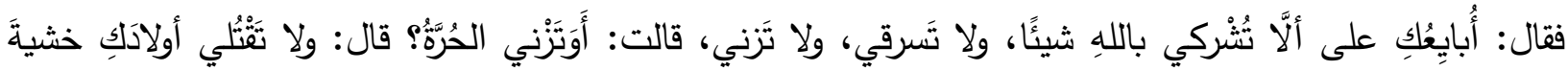

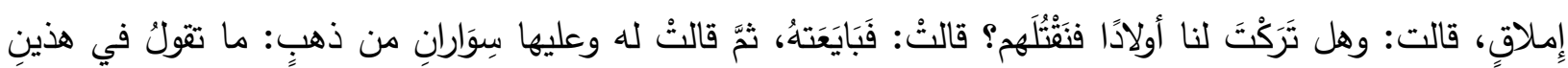

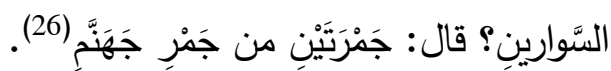
وشاهد الحديث، أن هندًا أنكرت أن تتلبس الحرة بالزنا، فدل ذلك على تقرير العفاف عندهم. والفطرة أن

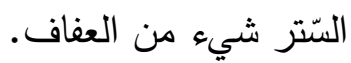
وفي الحديث، قال رسول الله صلى الله عليه وسلم: صنفان من أهل النار لم أرهما: رجال بأيديهم سياط

كأذناب البقر يضربون بها الناس، ونساء كاسيات عاريات، مائلات مميلات، رؤوسهن كأسنمة البخت المائلة (27). والحديث توثيق لما كانت عليه النساء في ذلك الزمن من نبذ العري والتكثف وطرق التحلل والتبرج، والتزام

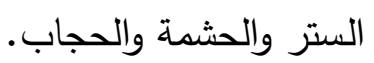

ومن عجيب المواقف؛ أن تحرص المرأة على سترها حتى بعد موتها، ومنه ما جاء عن فاطمة بنت محمد

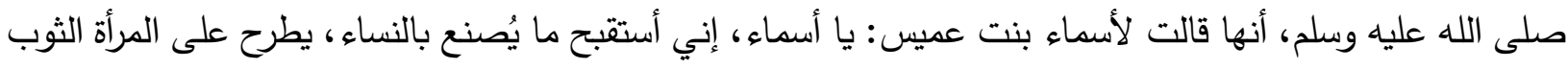

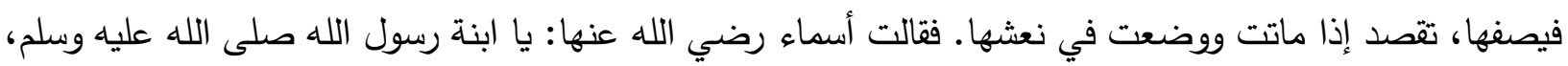

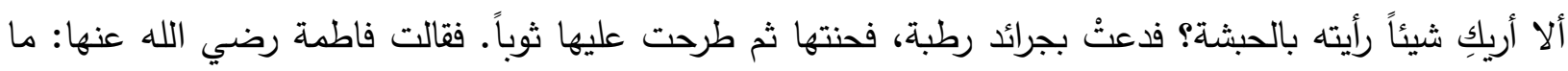

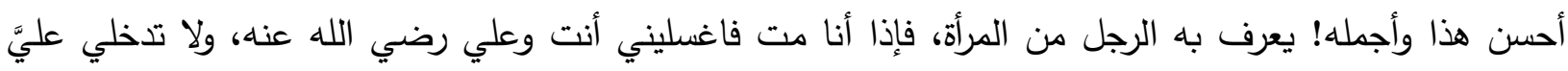
أحداً (28).

وعن أم المؤمنين عائشة رضي الله عنها، قالت: كنت أدخل بيتي الذي دفن فيه رسول الله وأبي، واضعة ثوبي، وأقول: إنما هو زوجي وأبي، فلما دفن عمر رضي الله عنه، فوالله ما دخلته إلا مشدودةً عليَّ ثيابي حياءً من الته عمر رضي الله عنه (29). وقد أثنى الله عز وجل، على الفتاة العفيفة، ابنة الرجل الصالح لاستحيائها في مشيتها، قال عزّ وجل:

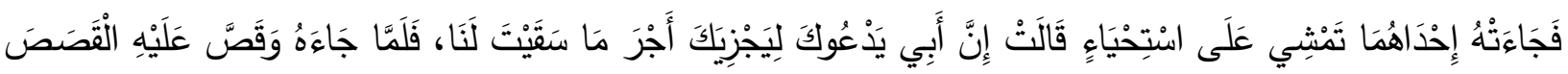

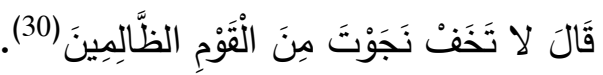

(26) أبو نعيم الأصبهاني، أحمد بن عبد الله، معرفة الصحابة، تحقيق عادل بن يوسف العزازي، ،دار الوطن-الرياض، سنة 1419 هـ، باب النساء، هِنُْ

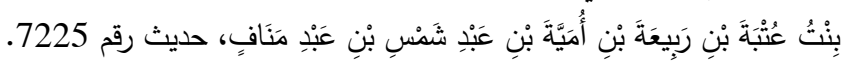

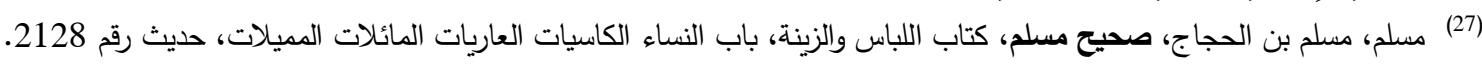

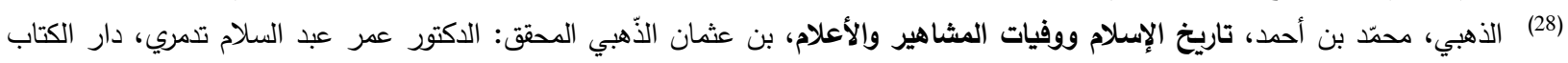

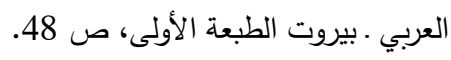

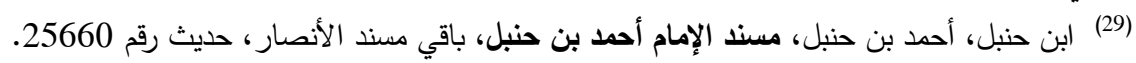

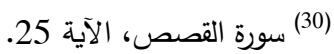


وكان مما تُحمَد به سيرة الرجل، أن يكون ذا نظرة طيبة طاهرة بريئة من الريب، أو له غض من البصر عند

التقائه بالمرأة الأجنبية. قال عروة بن الورد (31):

كمن باتَ تسري للصّديق عقاربُه

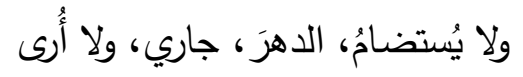

تغافلتُ حتى يستر البيت جانبه

إن جارتي ألوتُ رياح ببيتها

وقال عنترة(32):

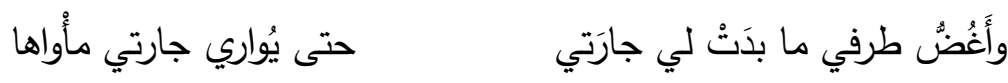

وللطائي كلام يذكر فيه رفده لجارته إذا غاب بعلها من دون زيارتها أو إلقاء نظرة عليها، تعففًا وفضيلة،

وحفظًا للمرأة وتأكيدًا على اعتداده بتصوّنها من دون أن يُقصر عليها ستر أو حجاب. فيقول(33):

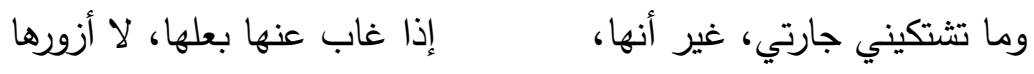

سيلغها خيري، ويرجع بعلها اليها، ولم يقصر ، عليَّ ستورها

ومن الرجولة، ترك النساء في الحرب فلا يُكشَف لحرة قناع، قال الثاعر (34):

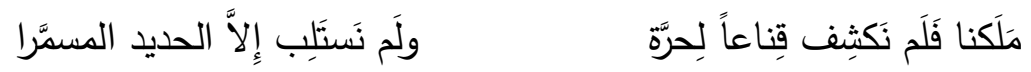

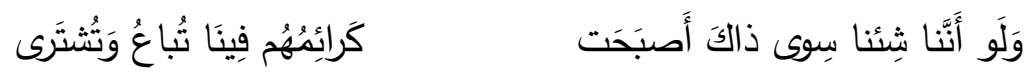

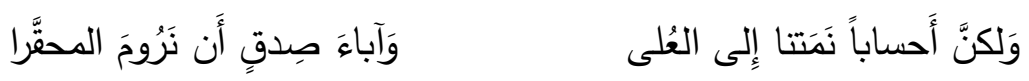

وهذا يدلّ على لبس الحرائر للقناع.

وعلى غير عادة العرب وفطرتهم وما جرى عليه الرأي عندهم، عدم التستر • بل عادة الحرائر عند العرب أن لن

يتدرعن وهن صغيرات. قال الثاعر (35):

وما قُلَّدَتْ إلا التّميَمَ المنظَّما

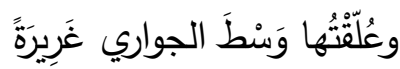

وترمي بعينيها إلى مَنْ تَكَرَّما

غيوفُ القذى تأبى فلا تعرفُ الخنا

وعادتُ ثُرى منهنَّ أبهى وأفخما

إلىى أن دعتُ بالدَّرع قبلَ لداتِها

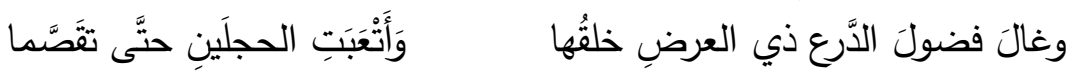

وللنساء، أنفسهن، حرص على الستر ، في حضور الأجانب، قال الثاعر (36):

فتتناولتهُ، واتقتتا باليدِ

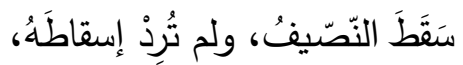

(31) عروة بن الورد، ديوان عروة بن الورد أمير الصعاليك، دراسة وشَرْح وتحقيق: أسماء أبو بكر محمد، دار الكتب العلميّة-بيروت، الطَّعة الأولىى، 1992م، ص 48.

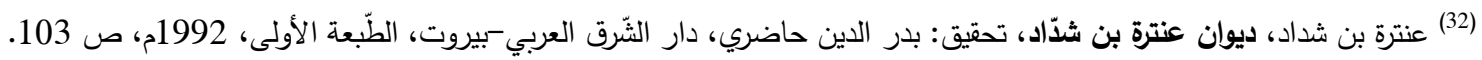

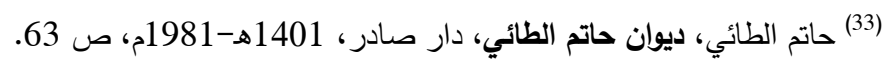

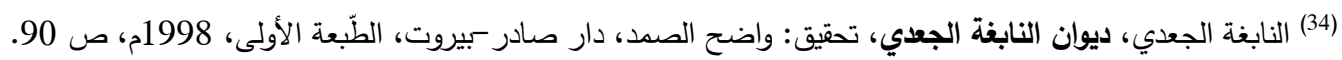

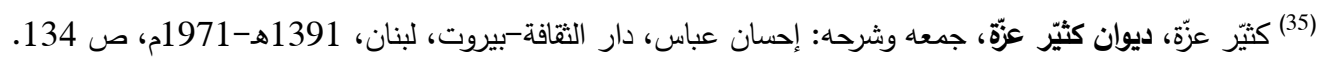

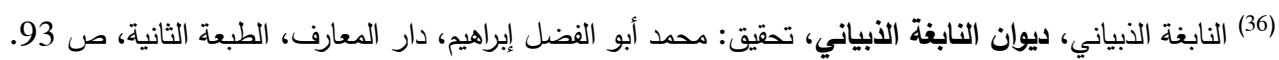


وفي النساء غيرة وحرص على أنفسهن أن تراهن عيون الرجال، ولهذا أسدلت عبلة حجاب وجهها عليها

حينما رأت عنترة، فقال(37):

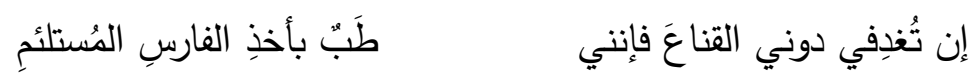

ويقال: أن توبة بن حمير الثاعر ، مجنون ليلى الأخيلية، كان إذا أتاها خرجت إليه في برقع. فلما شهر أمره

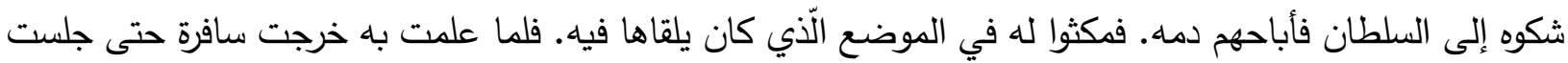
في طريقة. فلما رآها سافرة فطن لما أرادت وعلم أنه قد رصد وإنّها أسفرت لتحذره فركض فرسه فنجا. وذلك قوله (38):

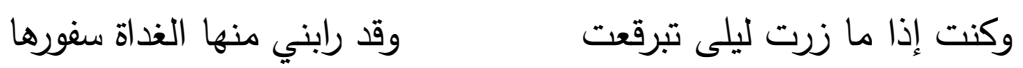

فظهر أنّ عادة الحرة الستر لا السفور • فإذا سفرت المرأة الحرة، فإن ذلك لأحد أسباب، منعها الاسلام، منها: الأوّل، الحزن والمصيبة، وكانوا يتواصون بذلك، يقول طرفة (39):

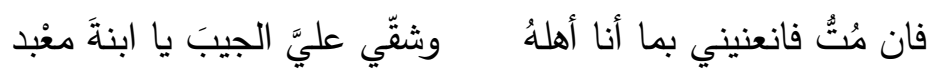

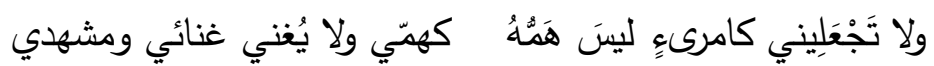

وعلى هذا كانت حال أهل الجاهلية، تخرج الحرة من خبائها عند المصائب، وتثق جيبها أو تمزق خمارها وتلطم على وجهها حاسرة الرأس والذراع جزعاً منها على فقيدها. قال الثاعر (40):

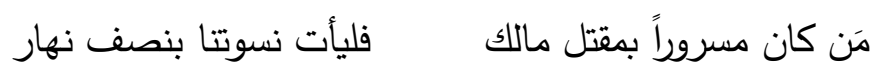
قد كنَّ يخبأن الوجوه تستراً

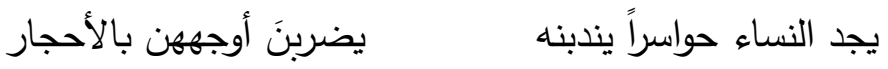

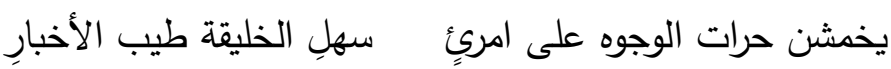

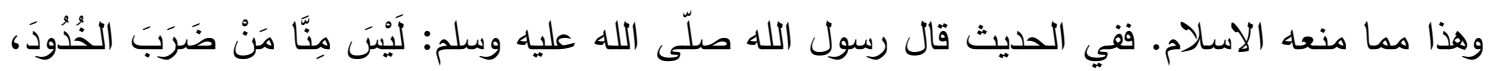

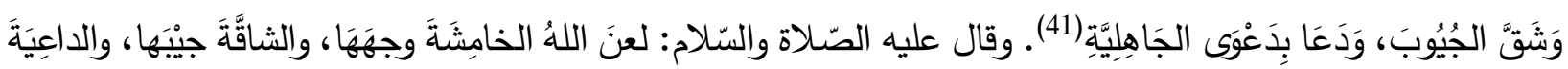
بالويْلِ والثُبورِ (42).

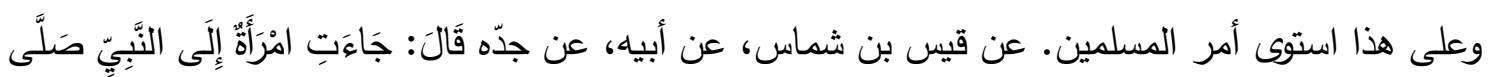

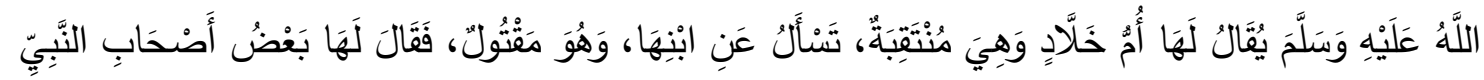

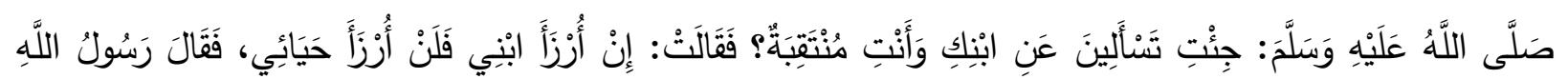

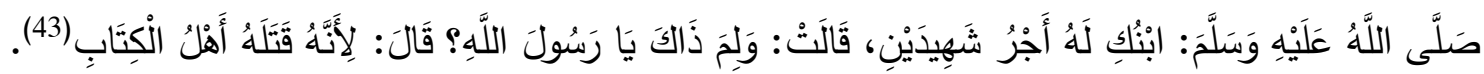

(37) عنترة بن شداد، ديوان عنترة بن شدّاد، ص 78 (137)

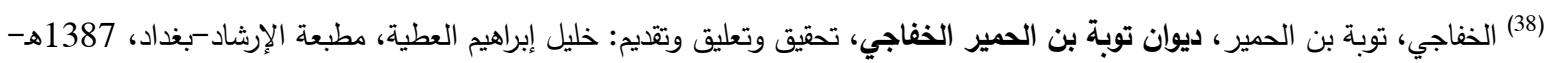
1968م، ص 30 (39) طرفة بن العبد، ديوان طرفة بن العبد، تحقيق: مهدي محمد ناصر الدين، دار الكتب العلمية، الطبعة الثالثة، 1423هـ-2002م، ص 29.

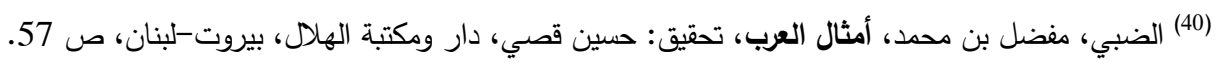

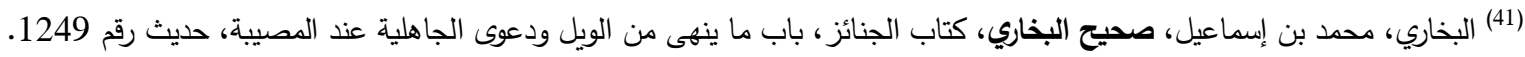
(42) جلال الدين السيوطي، عبد الرحمن بن أبي بكر ، التوشيح شرح الجامع الصحيح، تحقيق: رضوان جامع رضوان، مكتبة الرشد-الرياض، الطبعة

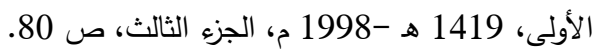

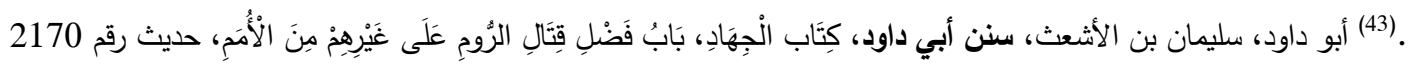


الثّاني، عند إبداء الحسن والزينة: فقد كانت الحرة في الجاهلية، تتخلى عن التزامها بالستر والحجّاب إبداء

للزينة في أيام خاصة كأيام الحجّ أو السفر • وقد تلقي المرأة خمارها لحسنها وهي على عفة. ومعناه أن العادة أن لا تلقي العفيفة خمارها. وليس أجمل من قول الثنفرى، وقد هجرته زوجته، فما هزه خطبه إلا أن ذكرها بأشد ما أعجبه منها، إنّها ما كانت تسقط قناعها تعدداً لإبداء حسنها، ولا تتلفت لكي لا تجلب الريبة لعفتها وخدرها، قال الشنفرى (44): ألا أم عمرو أجمعتُ فاستقلت وما ودّعتُ جيرإنّها إذْ تولتّتِ وقد سبقتنا أم عمرو بأمرها وكانتُ بأعناق المطي أظلتِتِ

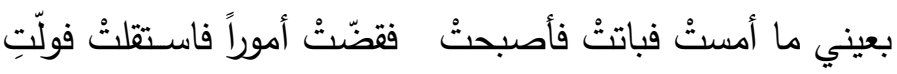

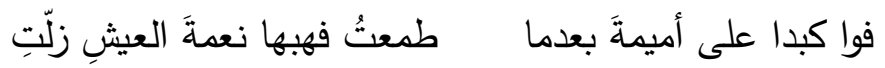
لقد أعجبتي لا سقوطاً قناعها إذا ما مشت ولا بذاتِ تلفّتِ قال الاعشى (45): (20) - (20)

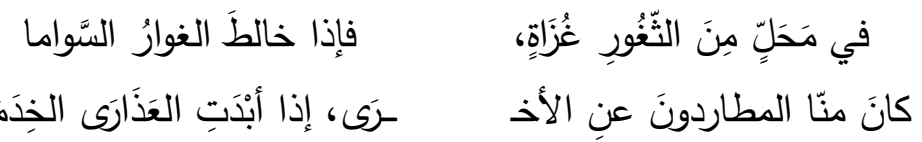

والخَِم: الخلخال. وإنّما كثفنه تزينا. وكان ستر الخلخال مما يفتخر به العرب. قال الأفوه الأودي يفتخر الأن بنساء قبيلته اللائي لا يرى ما يلبسن من حجل، وهو الخلخال(46):

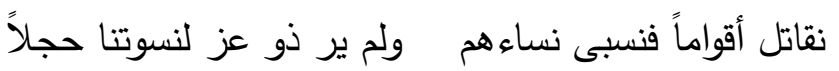
وتُمَّح المرأة، لا تضرب برجليها فيخفى حجلها، فلا يرى ولا يسمع، قال الهذلي (47): كظيم الحجل واضحة المحيا عديلة حسن خلقي في تمام

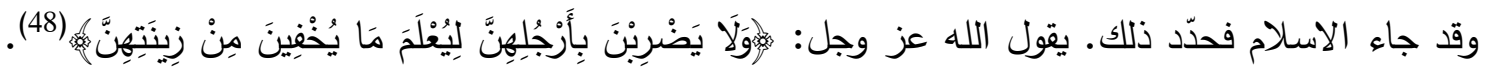

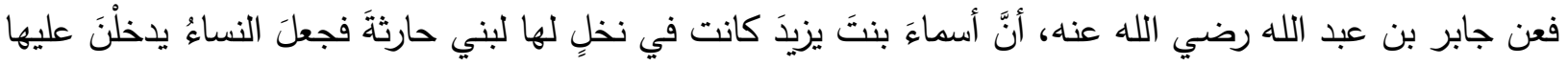

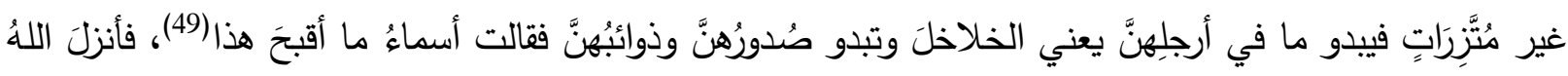

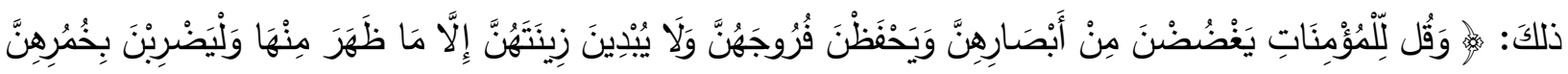

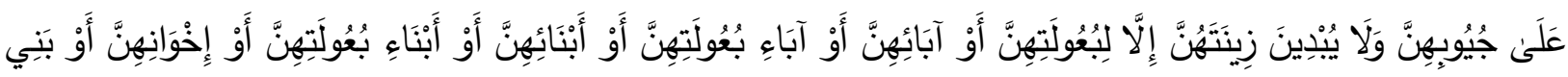

(44) الشنفرى، عمو بن مالك، ديوان الشنفرى، جمعه وحققه وشرحه: ايميل بديع يعقوب، دار الكتاب العربي، بيروت، الطبعة الثانية، 1417هـ-

(45) الأعثى الكبير، ميمون بن قيس، ديوان الأعشى الكبير، تحقيق: محمد حسين، مكتبة الاداب بالجماميزت، مصر ، ص 38 ،

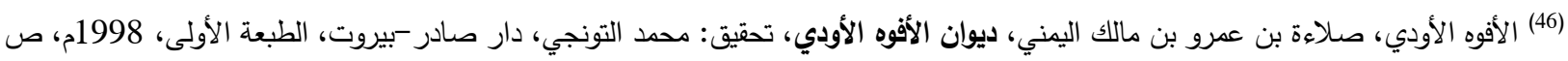
(47) السكري، الحسن بن الحسين، شرح أشعار الهذليين، تحقيق: عبد الستار أحمد فراج، مراجعة: محمود محمد شاكر، مكتبة دار العروبة-دار المدني،

(49) الثوكاني، محمد بن علي، فتح القدير الجامع بين الرواية والدراية من علم التفسير، ضبطه وصححه: أحمد عبد السلام، دار الكتب العلمية، 


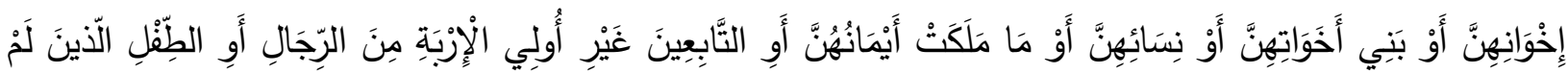

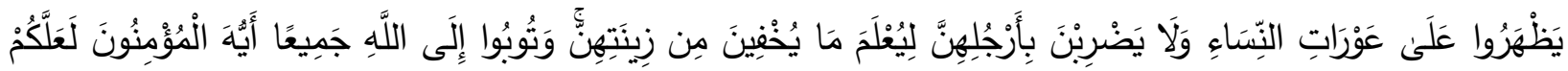
تَفِْحُونَ

الثّالث، الفقر والجوع: فمن دواعي السفور لاى المرأة الجاهلية معاناتها من الجوع والفقر حيث أحيانًا تؤدي بها إلى تركها التعزل والخفر وعدم احتجابها وحضورها محضر السوء سداً للجوع وكسباً للرزق. قال لبيد (51):

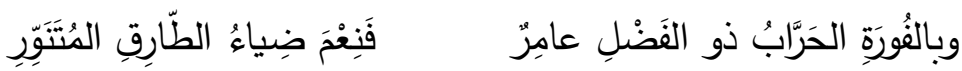

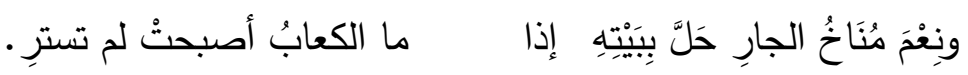

الترّابع، الخوف من السبي: كانت المرأة العربية الجاهلية تسفر في الحروب إذا أيقتت هزيمة قومها وخثيت

$$
\text { السبي فتتشبه بالأمة حتى يُزهَدَ فيها وتتأهب للفرار سافرة. }
$$

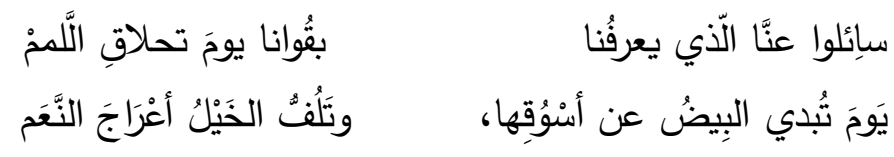

ويعتبر الحجاب في الإسلام فرض واجب، في الكتاب والسنة والإجماع، فلا يجوز للمرأة أن تخلعه، أو تفرط

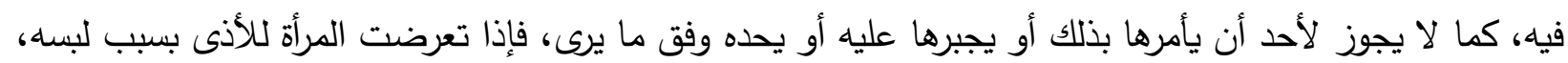

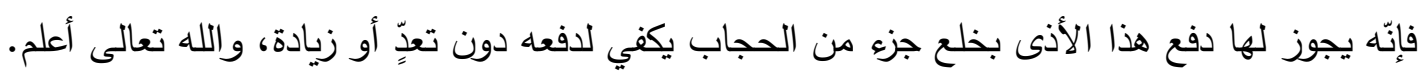

وقد كانت الحرة في الجاهلية ربما استترت بما يصف عظامها، فلا ترى بذلك بأسا. قال الأعشى(53):

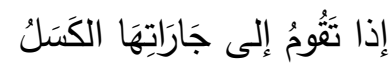

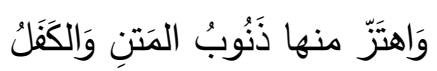

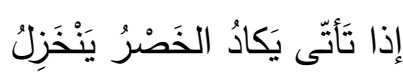

$$
\begin{aligned}
& \text { يكَادُ يَصَرَعُها، لَوْلا تَتَدَدْدَهَا، }
\end{aligned}
$$

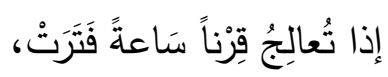

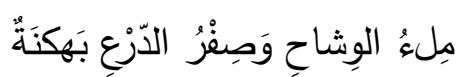

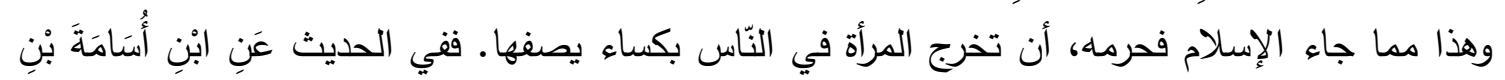

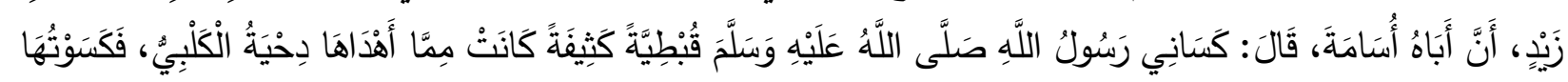

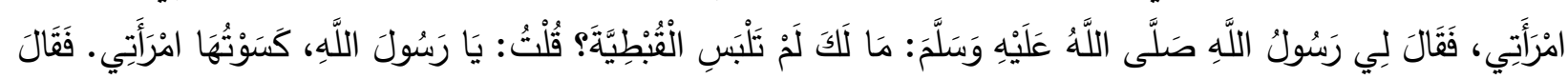

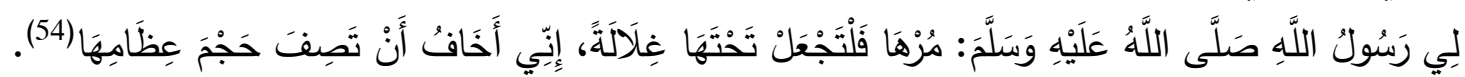

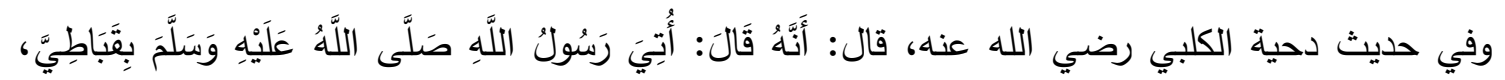

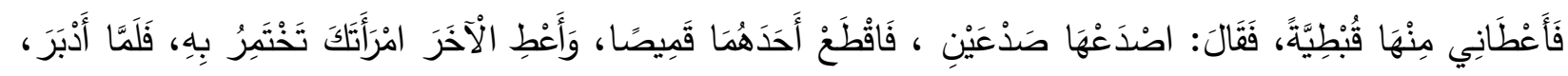

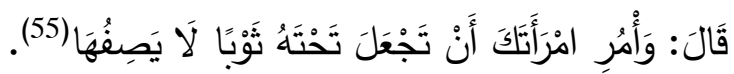

$$
31 \text { (50) سورة النور: الآية }
$$

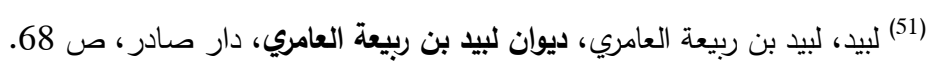

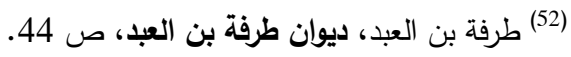

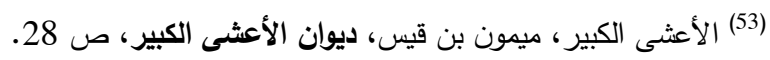

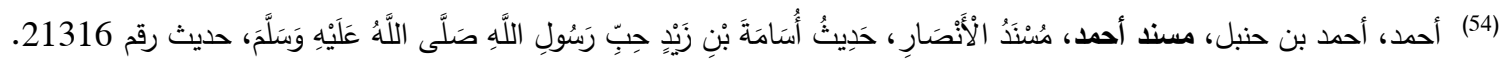

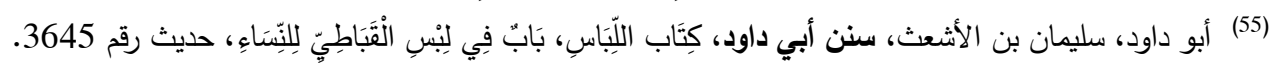




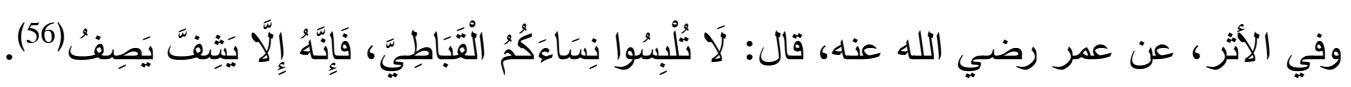
وإنّما ذكرت هذا ليُعلم ما كانت عادة النساء زمن النبي صلّى الله عليه وسلم في اللباس، فنعلم ما كان يمكن رؤيته من إحداهن، إذا هي غفلت، فيُقاس عليه فيما يمكن لمريد الزواج أن ينظر خفية، فيكون عليه الحكم في بيان قدر رؤيته من المخطوبة،، إذ لا يصح أن نقيس على هذا الزمان الّّي فسق فيه النّاس وتعودوا السفور والفجور •

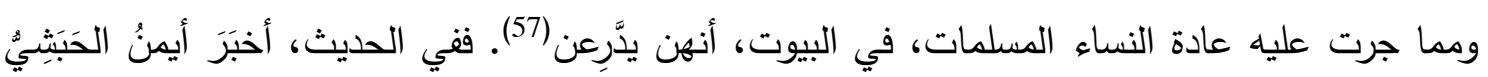

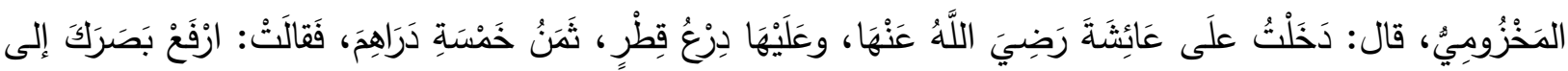

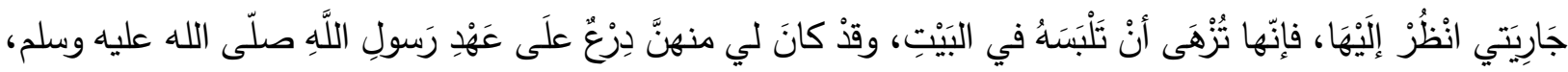

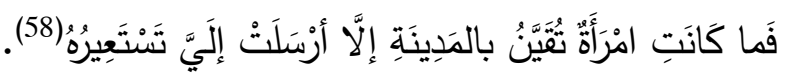

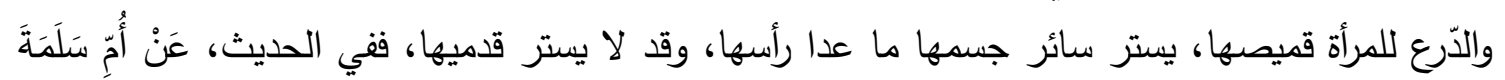

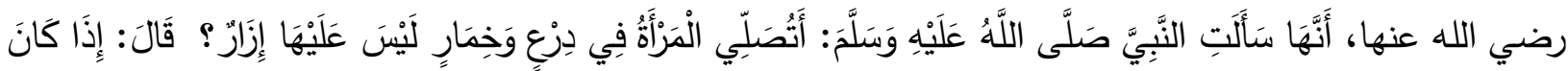

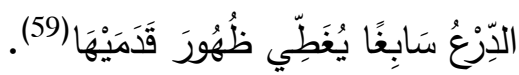
وقد تُكثَف أقدام المرأة المدرعة، إذا مشت وتحركت، وفي حديث أنس بن مالك رضي الله عنه، قال: لَمَّا

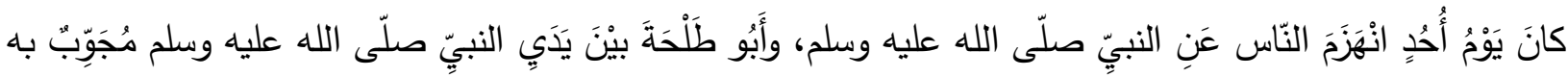

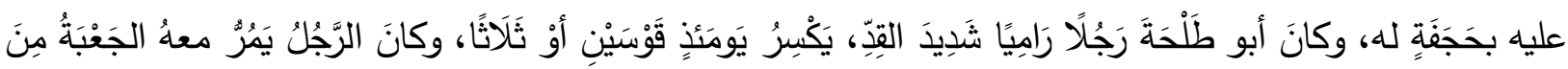

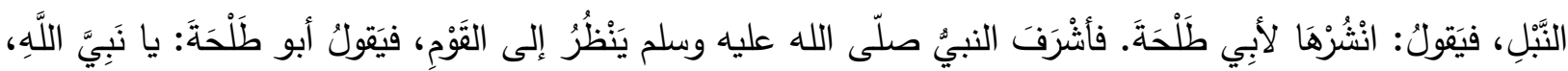

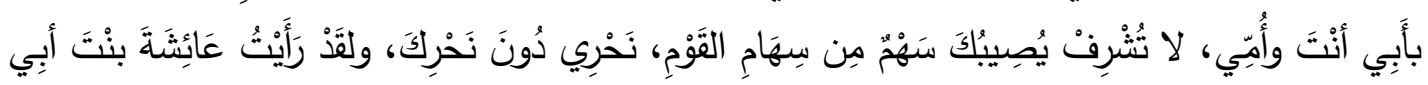

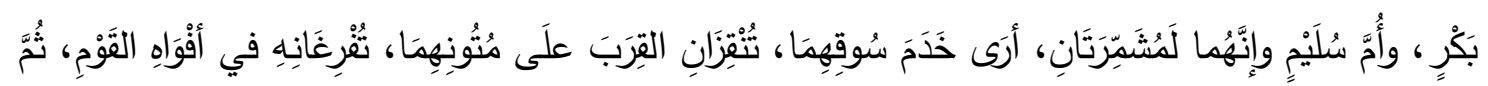

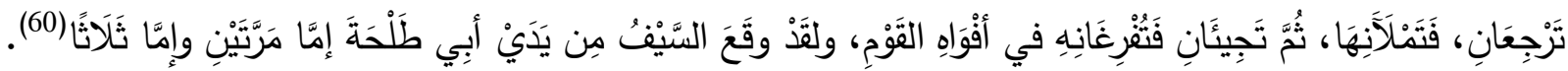

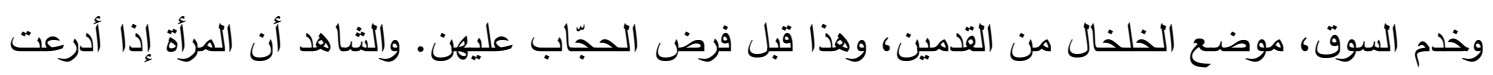
جاز طبيعة أن تشمِّر ثوبها فتُرى أقدامها.

وقد تتكثف أقدام المرأة المدرعة، إذا هي رفعت يدها لأخذ شيء من عَلِ أو حمله على رأسها. وفي حديث

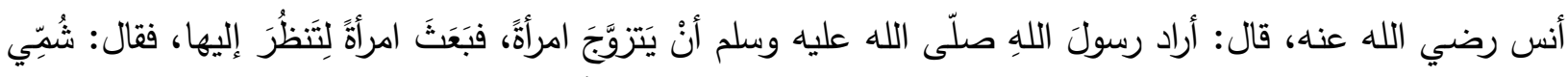

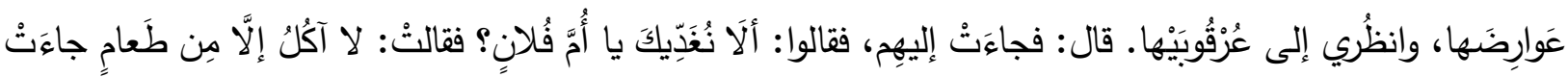

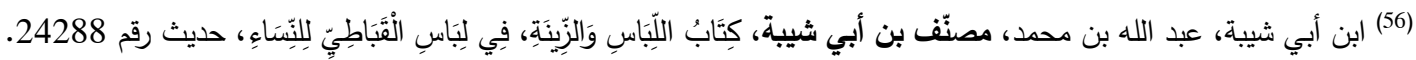

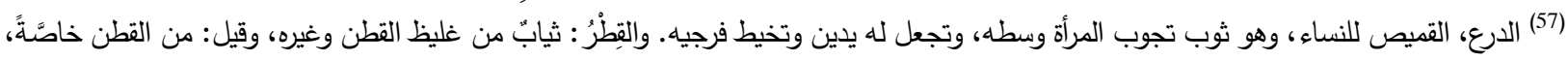

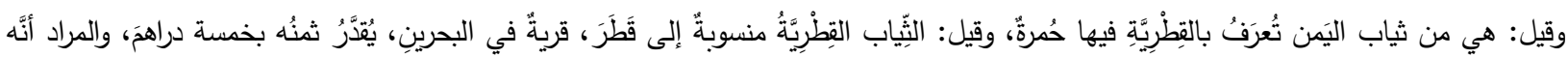

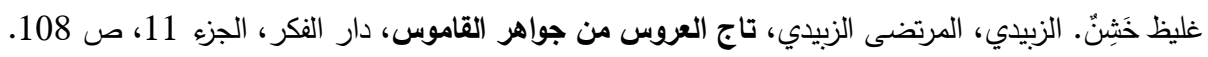

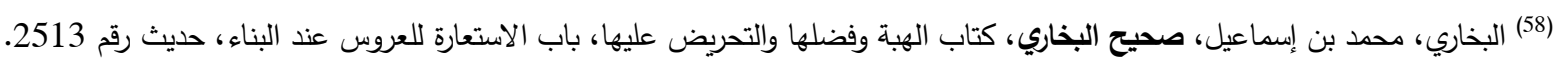

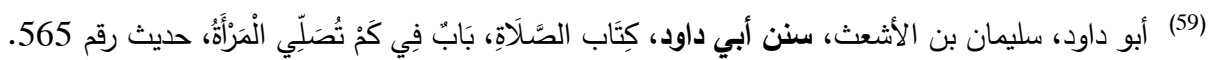

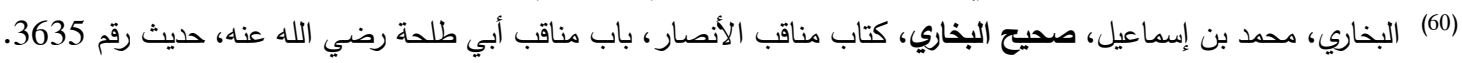




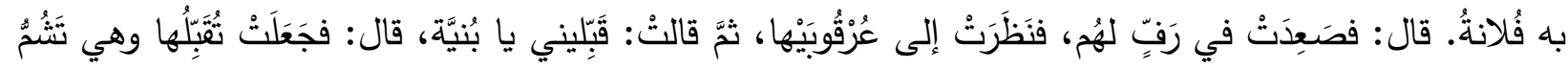

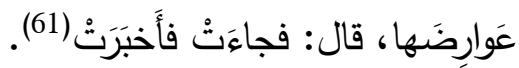

والعرقوب، خلف القدم. والّذي أظنه أنه يدل على كثرة الوضوء، وفي الحديث عن أبي هريرة رضي الله عنه،

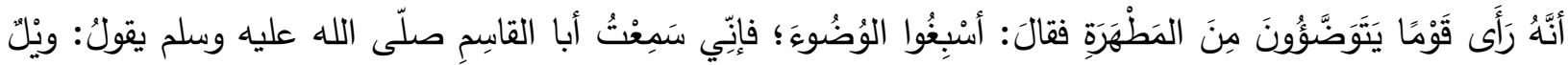
لِلْعَراقِيْبِ مِنَ النَّارِ (62).

وقيل: يدل على بقية الجسم لأَنَه إذذا اسْوَدَّ عَقِباها اسودَّ سائرُ جَسَدها. وربما دل على نظافة المرأة واهتمامها بنفسها. قال الثاعر (63):

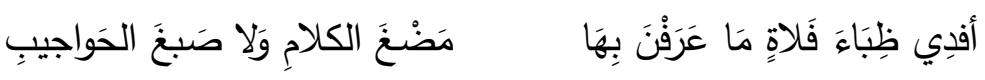

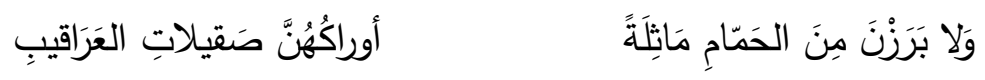

$$
\begin{aligned}
& \text { وقيل: يدل على صحة البدن، وامتلاء الجسم ونحافته، وقيل غير ذلك. }
\end{aligned}
$$

\section{أثر الثعر العربي في تحرير أقوال الفقهاء في حدود نظر الخاطب إلى مخطوبته.}

لا تقتصر الاستفادة من الثعر في قيمته الفنية والجمالية، أو في الحفاظ على اللغة، وإنما أيضًا في قيمته التأريخية التي لا تقل أهمية عن قيمته الفنية. وكما استفاد اللغويون من الثعر في إظهار فصاحة الألفاظ وبناء قواعد اللغة، واستفاد المؤرخون منه في استبيان ترتيب الأحداث التي وقعت يومئذ. نحاول أن نقدم في الفقرة التالية صورة أخرى من فن صور الاستفادة من الشعر فيما يتعلق بالفقه. حيث سنتناول تحرير مسألة القدر المباح للرّجل رؤيته من المرأة الأجنبية إذا نوى الزّواج بها وغلب على ظنّه قبول نكاحه منها. وسنعرض أقوال الفقهاء في المسألة، معتمدين في ترجيح تلك الأقوال العرف السائد في ذلك الزّمن فيما يمكن أن يظهر من المرأة في العادة إذا أمنت عيون الرّجال، من خلال ما تبيّن لنا في الفقرة السابقة فيما أوردنا من أشعار العرب في الجاهلية وبداية ظهور الإسلام. فمما يُعلَحم أنّه من تمام نعم الله على عباده أن خلق لهم من أنفسهم أزواجا يسكنون إليها، وجمع بينهما بالود

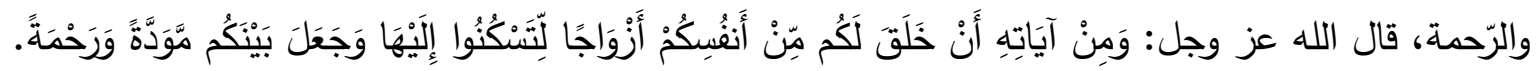
ولعل من عوامل ديمومة الزّواج وثباته، ما جاءت به الثريعة من إباحة نظر الخاطب إنب إلى مخطوبته. إلا أنّ لتلك الإباحة شروطًا وضوابط وقدرًا محدودًا.

ومن الضروري معرفة هذه الضوابط والثّروط وذلك القدر المباح رؤيته للرّجل من المرأة ينوي الزواج بها.

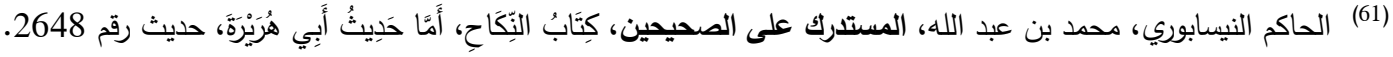

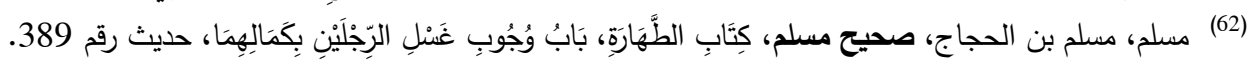

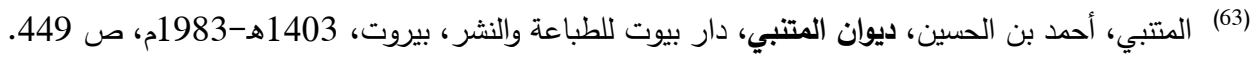


ومعلوم أن الأصل في البصر أن يُغَضَّ عن العورات والمحارم، من رجل وامرأة. فلا يجوز للرجل أن يطلق

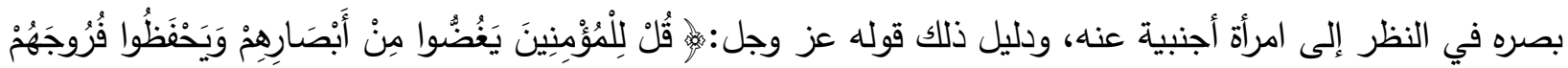

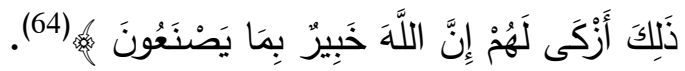

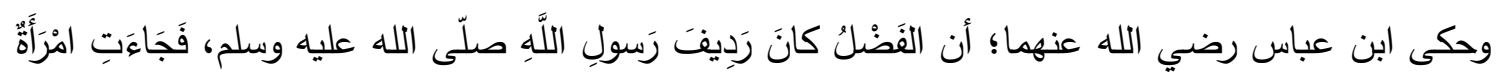

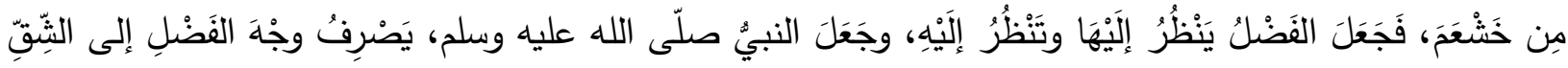

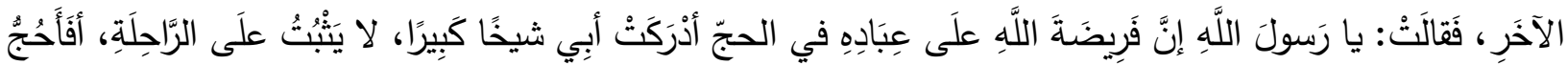

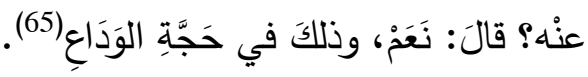
ويُباح ذلك في أمور (66)، كأن ينظر الرجل إلى المرأة، يريد الزواج منها وغلب على ظنه أنه يجاب إلى نكاحه(67) وكذلك يجوز للمرأة أن تتظر إلى من يتقدم لها، أو أرادت نكاحه، وعليه نص "المالكية"(68)، و"الثافعية"(69). وقال بعضهم باستحباب ذلك (70)، لحديث جابر بن عبد الله رضي الله عنه، قال، قال رسول الله صلّّى الله عليه وسلم: إذا خطب أحدكم المرأة فإن استطاع أن ينظر إلى ما يدعوه إلى نكاحها فليفعل، قال: فخطبت امرأة فكنت أتخبأ لها، حتى رأيت منها ما دعاني إلى نكاحها، فتزوجتها(71). وقال جماعة هو مباح (72). وللخاطب أن ينظر وجه مخطوبته وكفيها، لإمكان استدلاله بالوجه على الجمال أو ضده لأنه مجمع الحسن، كما يستدل بالنظر إلى الكفين على خصوبة البدن أو عدمه، وبه يتحقق مطلوب النظر • واختلفوا فيما سوى الوجه والكفين، لورود الأحاديث في إباحة النظر إلى المرأة لمن يريد نكاحها مطلقة، بلا تحديدٍ لما يمكن للخاطب أن يراه منها. والواقع إنّها نصت على الهدف من ذلك، من حيث الاطمئنان إلى وصف ظاهرها لتأكيد العقد.

$$
\text { (64) سورة النور: الآية } 30 .
$$

(65) البخارين محمد بن إسماعيل، صحيح البخاري، كتاب جزاء الصيد، باب حج المرأة عن الرجل، حديث رقم 1769. (66) يباح للرجل النظر إلى المرأة، بحدود الحاجة، عند مداواتها وتوليدها وتمريضها، وعند الثهادة والحكم لها أو عليها. وعند معاملتها أو تعليمها، وعند النهاء

(67) يحل النظر إلى مواضع الزينة، الكاساني، أبو بكر بن مسعود، بدائع الصنائع في ترتيب الثرائع، الجزء 5، ص البـ 122. وأجاز مالك النظر إلى المرأة

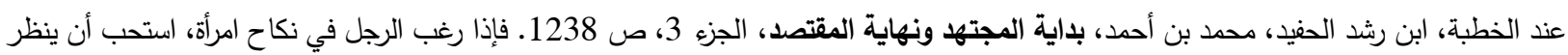

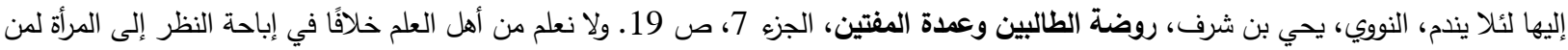

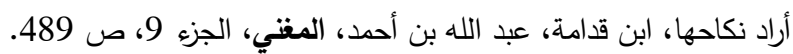

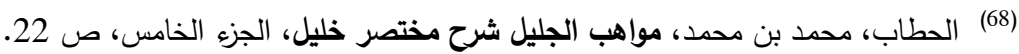

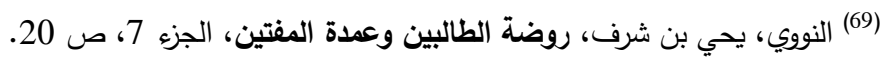

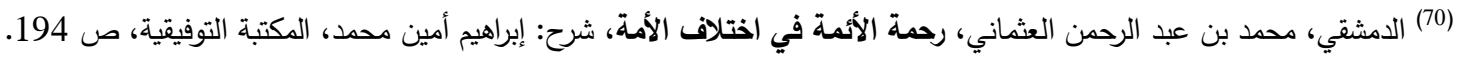

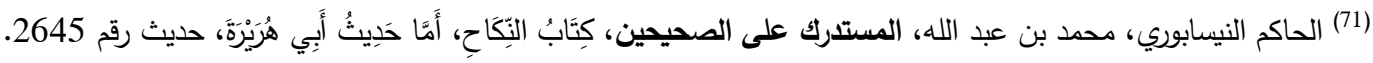

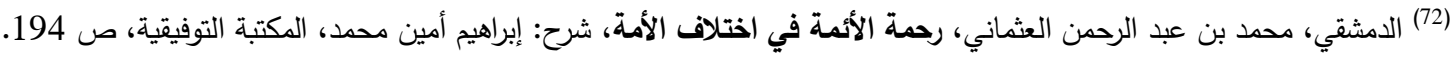


فذهب الجمهور من "الحنفية"(73)، و"المالكية"(74)، و"الثافعية"(75)، إلى القول بالاقتصار في الرؤية على الوجه والكفين.

والمشهور عند "الحنابلة"(76)، أنّ من أراد التزوج بامرأة فله أن ينظر إلى ما يظهر غالبًا كالوجه والرقبة واليد

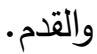

وذهب الظاهرية إلى أن من أراد أن يتزوج امرأة حرة أو أمة، فله أن ينظر منها متغفلاً، وغير متغفل إلى ما بطن منها وما ظهر، ومعناه يجوز لله أن ينظر إلى جميع بدنها ماعدا العورة المغلظة وهي السوأتان. واستدلوا بعموم الأحاديث المتقدمة، الّتي تبيح النظر إلى من يريد نكاحها. قالوا فهذه الأحاديث تُعد عموماً مُخرِجًا لهذه الحال من جملة ما حرم من غض البصر (77).

قلت: أما النّصّوص فلا يُفهَم منها البتة، إباحة النظر لسائر البدن، إنّما دلت على جواز رؤية ما يظهر غالبا، والأصل في هذا أن نعود إلى العرف الّذي كان عليه القوم، حيث عُرفت الحرائر، حتى زمن الجاهلية، بالستر والعفاف. وقد أتينا على بيانه. وقد تتوظأ المرأة فيُرى ذراعها وشعرها. وفي الحديث عن عبد الله بن عمرو رضي الله عنه، قال: كان الرجالُ

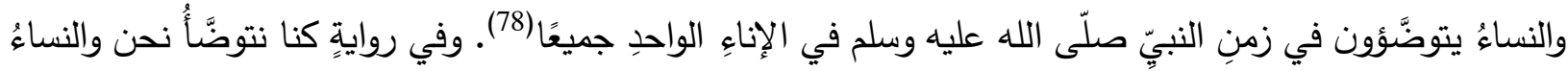

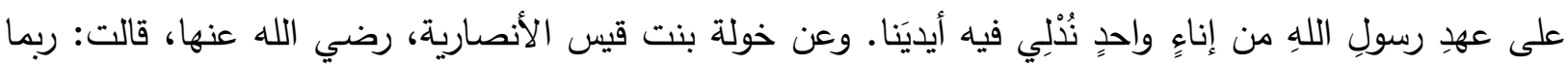

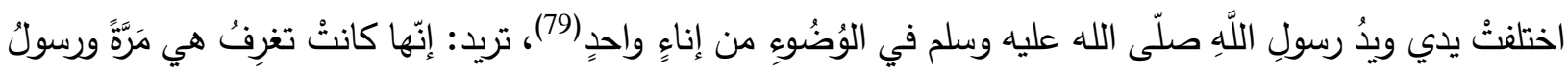
اللهِهِ صلّى الله عليه وسلم مَرَّةً من نفس الإناء.

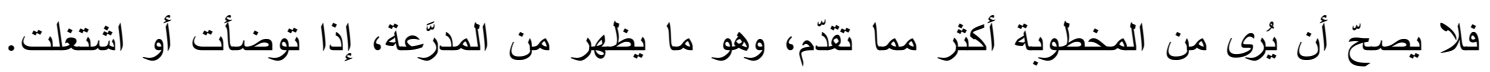
ومحصّل ذلك، الرأس والوجه واليدان والقدمان. ودليل أنه يحرم أكثر من ذلك، حديث عائشة رضي الله عنها، قالت: كانَ يَذْخُلُ علَى أَزْوَاجِ النبِيّ صلّى

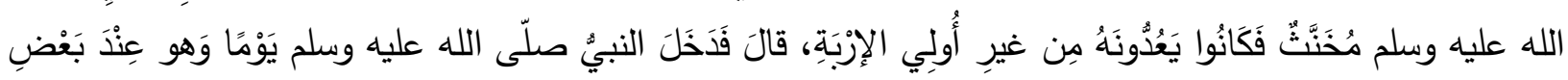

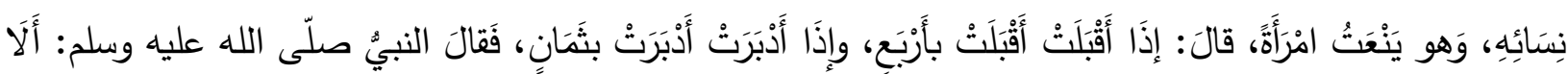

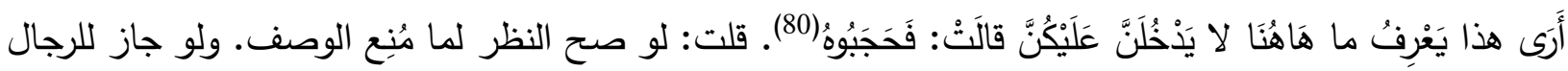

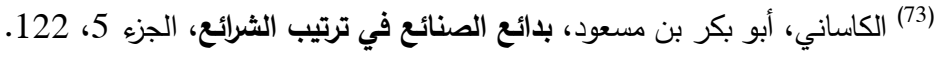

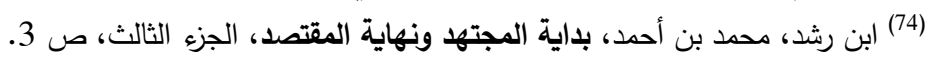

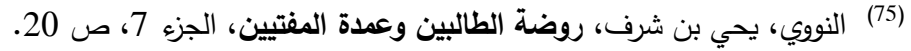

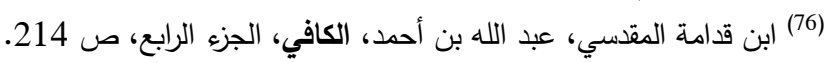

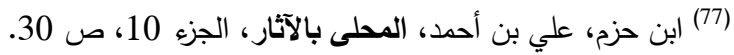

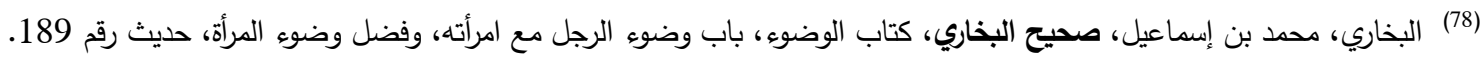

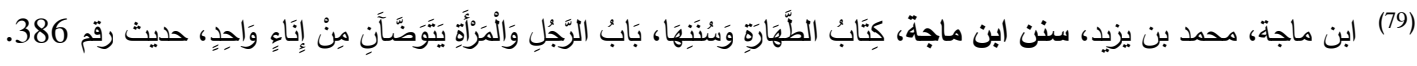

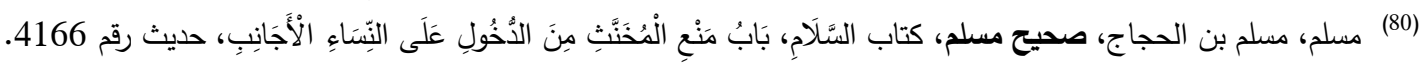


النظر ما حُكِم على هيت بالنفي (81). وفي الحديث، عن عبد الله بن مسعود رضي الله عنه، أن رسول الله صلّى الله

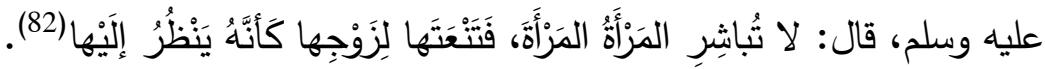
وقد أخطأ من أباح النّر في كل جسد المرأة، ظاهرا وباطنا. كقول من قال: من أراد أن يتزوج امرأة حرة أو أو أمة، فله أن ينظر منها متغفلاً، وغير متغفل إلى ما بطن منها وما ظهر (83). ولعله خطأ النقال في فهر كلامه لذكره ما بطن منها، فقاسوه عما أحدثه النّاس اليوم من التعري في البيوت وخارجه، وهو قياس باطل، إنّما يُحمَل كلامه على في ما كان، لا على ما أحدثه أهل هذا الزمان من الفسق. ولا يشترط في جواز النّظر لمن وقع في قلبه نكاح امرأة أن يستأذنها، أو وليَّها، إذا غلب عليه قبول نكاحها

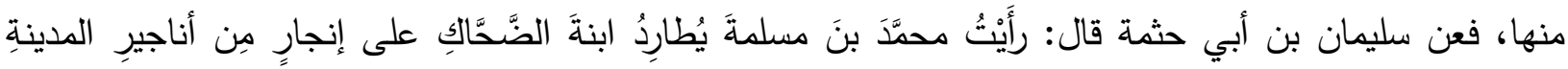

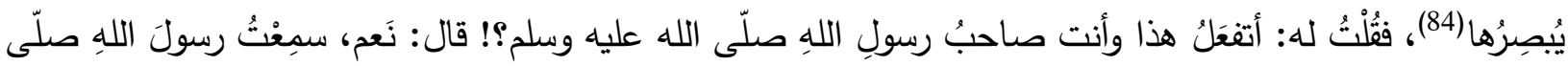

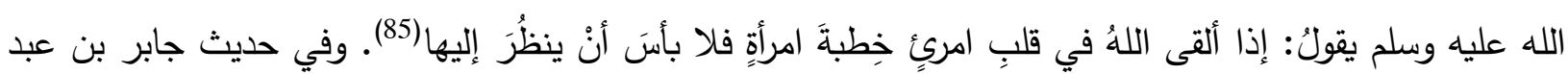
الله رضي الله عنهن قال: قال رسول الله صلّى الله عليه وسلم: لا جناح على أحدكم إذا أراد أن يخطب المرأة أن يغترها(86)، فينظر إليها، فإن رضي نكح، وإن سخط ترك(87).

(81) في المثل: أخنث من هيت. قال: هذا المثل من أمثال أهل المدينة، سار على عهد رسول الله صلى الله عليه وسلم، وكان حينئذ بالدينة ثلاثة من

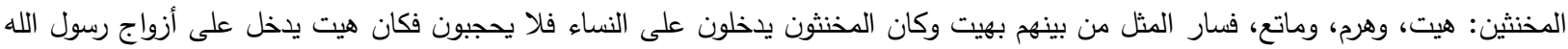

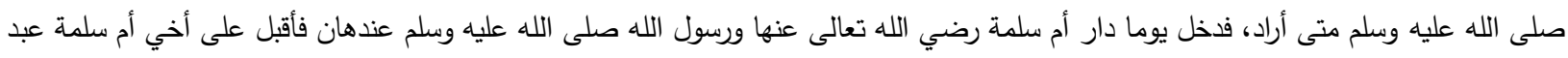

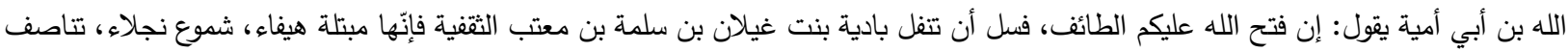

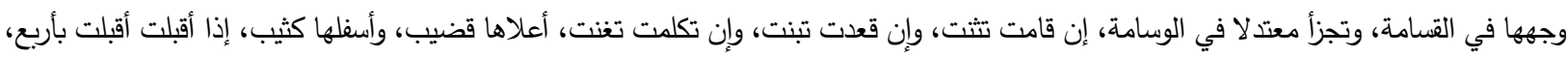

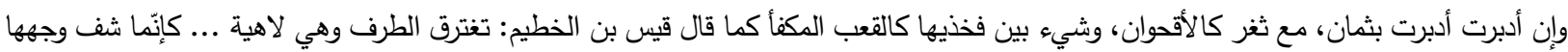

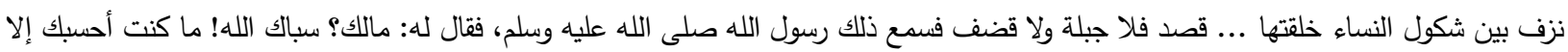

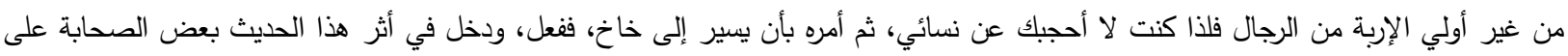

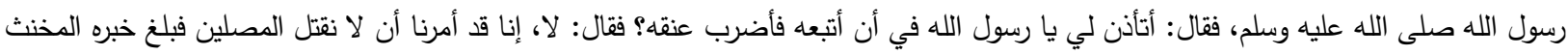

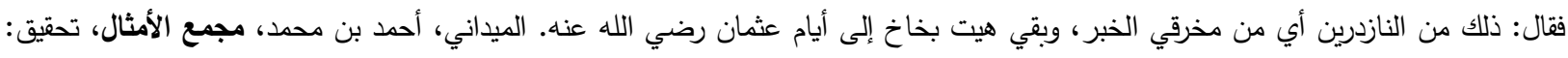

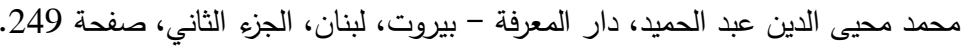

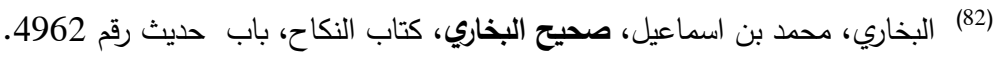

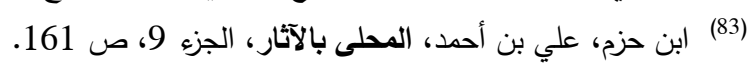

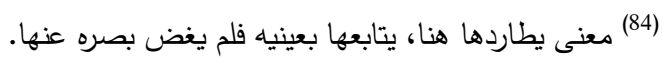

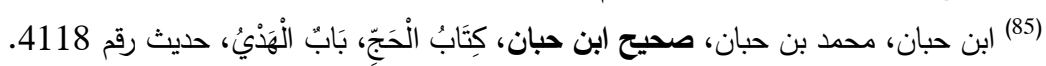

(86) معنى يغترها، يستغفلها فيسترق النظر إليها.

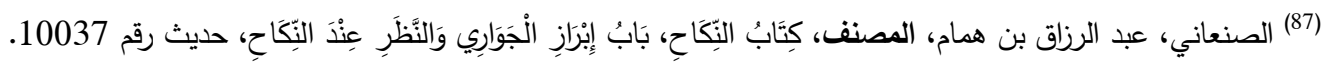


وعلى هذا مضى قول الجمهور من "الحنفية"(88)، و "الثافعية"(89)، و"الحنابلة"(90.) وقال "المالكية" أن من أراد تزويج امرأة نظر إليها بإذنها، وكره مالك أن يغفلها سدا للذّريعة، مخافة أن يتسبّب أهل الفساد بالنظر فإذا اطلع عليهم، قالوا: كنّا خطابا(91).

فإذا عزم أو تقدم، فله أن ينظر إليها بعلمها أو بدونه، كما في الحديث عن أبي حميد الساعدي أن رسول الله صلّى الله عليه وسلم: إذا خطب أحدُكم المرأةَ، فلا جناح عليْه أنْ ينظرَ إليها، إذا كان إنّما ينظرُ إليها لخِطبتِه، إنها

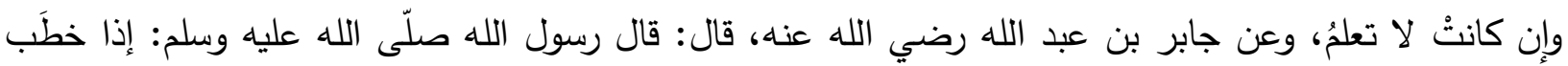

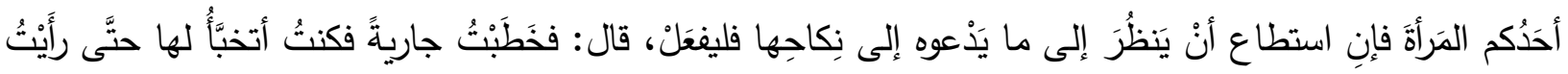

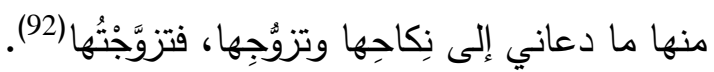
وله أن يطلب من وليّها أن يرى وجهها، ولا يمنعه إذا كان موافقا على نكاحه منها، ففي الحديث عن المغيرة

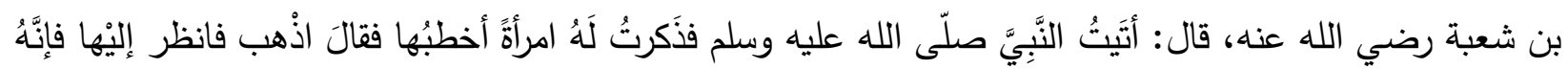

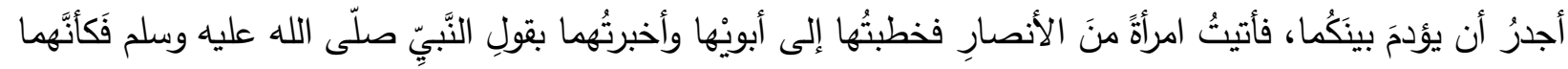

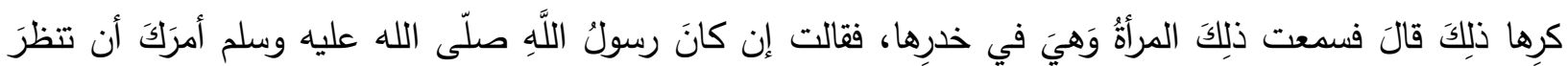

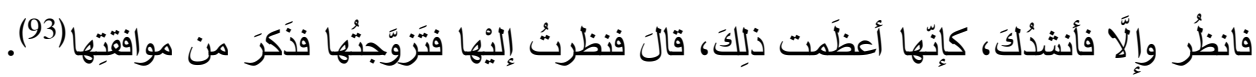
فإن غلب على ظنه أن لا يُقبل طلبه بالنّكاح، فلا يحل لله من ذلك شيء.

ولا تجوز الخلوة بالمخطوبة كغيرها من الأجنبيّات، لحديث عمر رضي الله عنه، قال: قال رسول الله صلّى

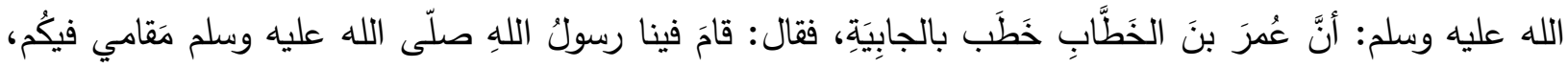

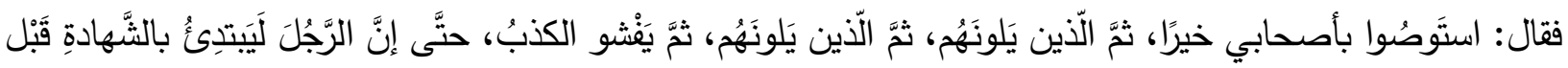

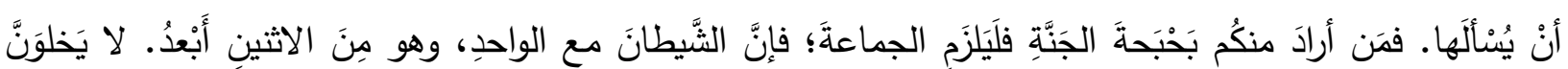

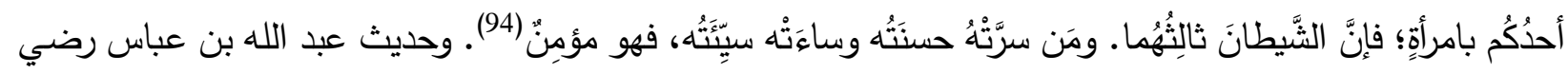

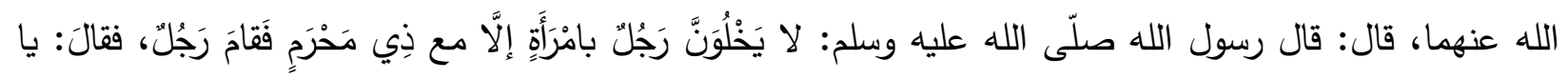

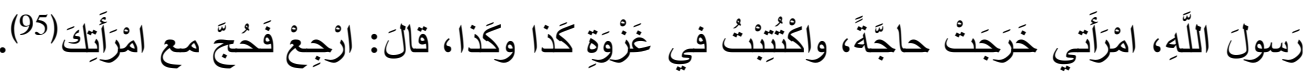
فإن اضطرّ إلى ذلك عن غير قصد فليِِفَّ نفسه وليتعفّف في الحديث إليها، كما في حديث عائشة: فَتَيَمَّمْتُ مَنْزِلِي

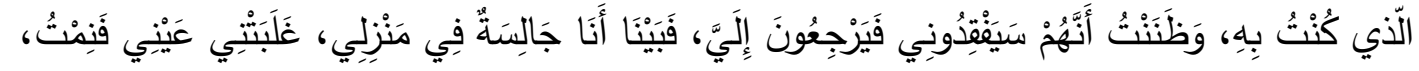

(88) ابن عابدين، محمد أمين، حاشية رد المحتار على الار المختار شرح تنوير الأبصار، الجزء 4، ص 80.

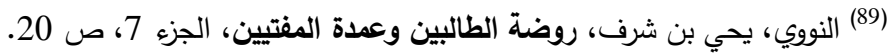

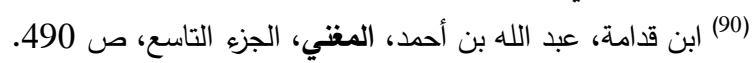

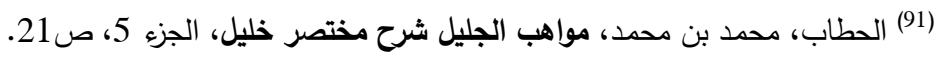

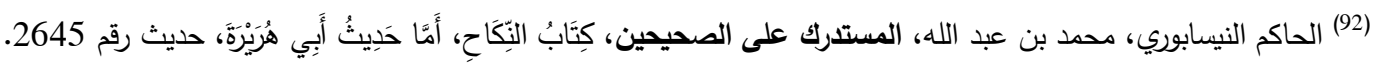

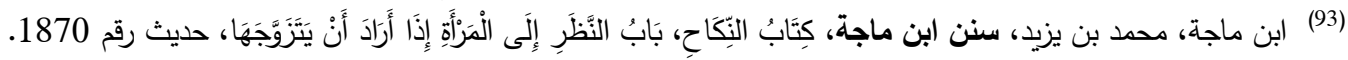

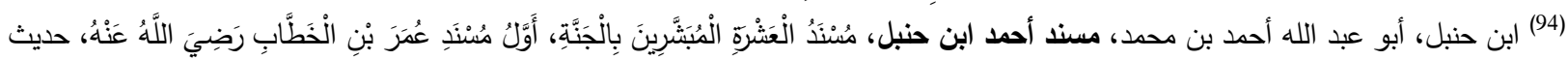
(95) البخاري، محمد بن إسماعيل، صحيح البخاري، كتاب النكاح، باب لا يخلون رجل بامرأة إلا ذو محرم، والدخول على المغيبة حديث رقم 4955. 


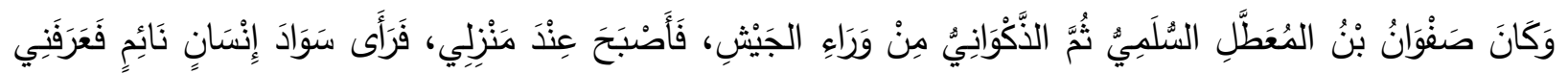

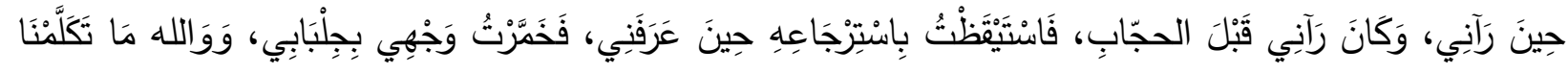

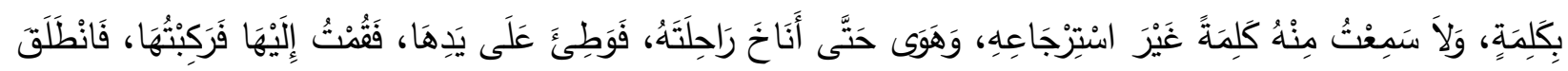

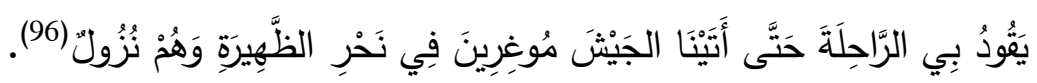
ويجوز توكيل الرّجل امرأةً أمينةً تتظر إلى من يريد نكاحها، ثم تصفها له. وفيه حد بما يمكن وصفه، وهو ما ذكرنا.

\section{الخاتمة}

خلصت الدراسة إلى أن قيمة الثعر العربي في فترة الجاهلية وبداية ظهور الإسلام، لا تقتصر على حفظ اللسان العربي

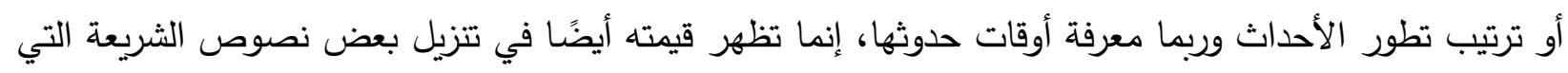
ارتبطت بأعراف ذلك الزمان ونواميس تلك الحضارة حتى تُقهَم الفهم الصحيح الذي يدفع الزلل عن صاحبه. فالمعلوم أن اللغة، غير اللسان، تتطور وتتغير والحضارة كذلك. وأنّه من غير الجائز عقلا أن نتزل ألفاظ النصوص السابقة على معانيها المبتكرة أو حملها على حضارة اليوم، بل الأصل أن تحمل على واقعها وتفهم على تلى معاني ألفاظها يومئذ. ويعتبر الثعر بعضُ مما يحفظ ذلك ويصوره لنا غضًّا كما هو كائن وقتها. - - أظهر البحث الثراء القيمي الذي كان عليه العربي رغم جهالته. وهو ثراء اختص به العرب عن غيرهم حتى تطبّعت به شخصية العربي فأظهره حياة يعيشها. - أظهر البحث أن العرب لم يكتفوا بممارسة المنظومة الأخلاقية لديهم بل سارعوا إلى تثبيتها وتوريثها من خلال أشعارهم. فالثعر عندهم لم يكن لتلميع الصورة والتعمية عن السوءات والرذائل إنما لتثبيت تلك القيم. - - تبيّن من خلال البحث أن قيمة الشعر تفوق ما اشتهر كونه نظامًا فنيَّا وتصويرًا ابداعيًا، فتتعدد تبعًا لذلك وجوه الاستقادة منه في التاريخ والفقه وغيره. - - تبيّن من خلال البحث أنه يجوز للرّجل إذا أراد التزوج بامرأة وغلب على ظنه قبول فئل نكاحه منها أن ينظر إلى ما يظهر منها غالبًا كالوجه والرقبة واليد والقدم. ويقاس ذلك على زمن البعثة لا على زمننا الذي تعرّت فيه النّساء وعرضت فئ فيه صورها بكامل الزّينة على صفحات التواصل الاجتماعي. كما يباح للرجل النظر إلى المرأة، بحدود الحاجة، عند مداواتها وتوليدها وتمريضها، وعند الثهادة والحكم لها أو عليها. وعند معاملتها أو تعليمها. 


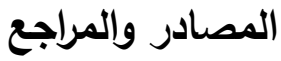

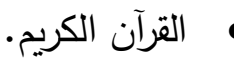

أحمد، أحمد بن حنبل، المسند للإمام أحمد بن حنبل، شرحه وصنع فهارسه: حمزة أحمد الزين، الطبعة الأولى، دار

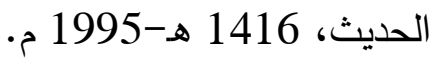

• الأعشى الكبير، ميمون بن قيس، ديوان الأعشى الكبير، تحقيق: محمد حسين، مكتبة الاداب بالجماميزت، مصر . الأعلم الثنتمري، يوسف بن سليمان (المتوفى: 476هـ)، أشعار الثعراء الستة الجاهليين، منشورات دار الآفاق الجديدة بيروت، الطبعة الثالثة، 1403هـ-1983م. هالأفوه الأودي، صلاءة بن عمرو بن مالك اليمني، ديوان الأفوه الأودي، تحقيق: محمد التونجي، دار صادر -بيروت،

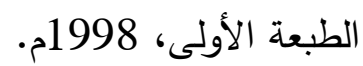
الألوسي، محمد شكري، بلوغ الأرب في معرفة أحوال العرب، تحقيق: محمد بهجة الأثري، دار الكتاب المصري، الطبعة الثانية.

• أوس بن حجر، ديوان أوس بن حجر، المحقق: محمد يوسف نجم، دار بيروت، 1400 هـ-1980م. البخاري، محمد بن إسماعيل (المتوفى: 256هـ)، صحيح البخاري، الطبعة الأولى، دار ابن كثير - دمثق بيروت سنة دانة النشر: 1423 هـ- 2002م. جال الدين السيوطي، عبد الرحمن بن أبي بكر، التوشيح شرح الجامع الصحيح، تحقيق: رضوان جامع رضوان،

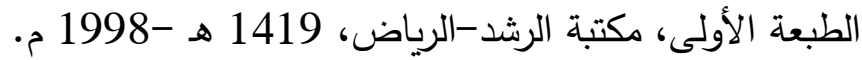
ابن جني، عثمان، الفنر - شرح ابن جني الكبير على ديوان المتنب، حققه وقدم له: رضا رجب، دار سعد الدين،

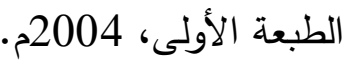
الجمي، محمد بن سلام، طبقات فحول الثعراء، (المتوفى: 323 هـ)، تحقيق: محمود محمد شاكر ، دار المدني بجدة،

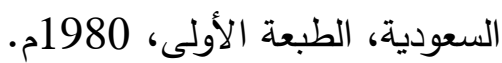

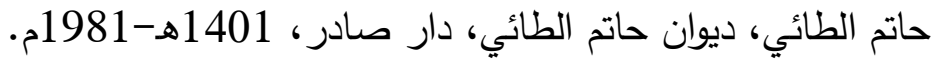
ه الحاكم النيسابوري، محمد بن عبد الله (المتوفى: 405هـ)، المستدرك على الصحيحين، الصني، تحقيق: مصطفى عبد القادر عطا، الطبعة الأولى، دار الكتب العلمية -بيروت، 1411 هـ- 1990م. الحصري القيرواني (ت 453 هـ)، إبراهيم بن علي، جمع الجواهر في الملح والنوادر (ذيل زهر الآداب)، تحقيق: علي محمد البجاوي الطبعة الثانية، 1407 هـ، دار الجيل. الحطاب، محد بن محمد (المتوفى: 954ه)، مواهب الجليل شرح مختصر خليل، الطبعة الثالثة، دار الفكر ، 1412هـ 1992 الحموي، تقي الدين أبو بكر بن حجة (الكتوفى: 837هـ)، خزانة الأدب وغاية الأرب، تحقيق: عصام شقيو، دار ومكتبة الهلال-بيروت، دار البحار -بيروت، 2004م. الخزاعي، دعبل بن علي، شعر دعبل بن علي الذزاعي، صنعه: عبد الكريم الأشتر، مطبوعات مجمع اللغة العربية بدمشق، الطبعة الثانية، 1403هـ-1983م.

الخفاجي، توبة بن الحمير، ديوان توبة بن الحمير الخفاجي، تحقيق وتعليق وتقديم: خليل إبراهيم العطية، مطبعة

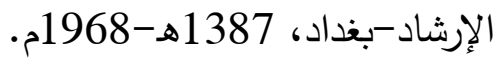


ابن حبان، محمد بن حبان (المتوفى: 354هـ)، الإحسان في تقريب صحيح ابن حبان، ترتيب: الأمير علاء الدين علي بن بلبان الفارسي (المتوفى: 739 هـ)، حققه وخرج أحاديثه وعلق عليه: شعيب الأرنؤوط، الطبعة الأولى، مؤسسة الرسالة، بيروت، 1408 هـ-1988 م.

ابن حزم، علي بن أحمد (المتوفى: 456هـ)، المحلى بالآثار ، تحقيق: عبد الغفار سليمان البنداري، دار الكتب العلمية

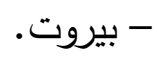

أبو داود، سليمان بن الأشعث (المتوفى: 275هـ)، سنن أبي داود، تحقيق: شعيب الأرناؤوط وآخرون، الطبعة الأولى،

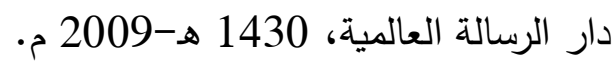

الامشقي، محمد بن عبد الرحمن العثماني، رحمة الأئمة في اختلاف الأمة، المكتبة التوقيفية. الذهبي، محمّد بن أحمد، تاريخ الإسلام ووفيات المشاهير والأعلام، بن عثمان الذّهبي المحقق: الدكتور عمر عبد السلام تدمري، دار الكتاب العربي • بيروت الطبعة الأولى.

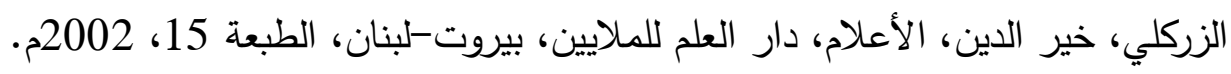
ابن رشد، محمد بن أحمد (المتوفى: 595هـ)، بداية المجتهد ونهاية المقتصد، دار الحديث - القاهرة، 1425هـ 2004

زعبي، حسين علي، النقد في رسائل النقد الثعري: حتى نهاية القرن الخامس الهجري، دار الفكر المعاصر، 2001م. السراج، جعفر بن أحمد (المتوفى: 500هـ)، مصارع العشاق، دار صادر، بيروت، الجزء الثاني، ص 6. السكري، الحسن بن الحسين، شرح أشعار الهذليين، تحقيق: عبد الستار أحمد فراج، مراجعة: محمود محمد شاكر، مكتبة دار العروبة-دار المدني.

السليك بن عمير بن يثربي بن سنان السعدي التميمي (ت 17 ق.هـ)، السليك بن السلكة اخباره وشعره، دراسة وتحقيق: حميد آدم ثوينى -كامل سعيد عواد، مطبعة العانى -بغداد، الطبعة الاولى -1404هـ -1984م. سويد بن أبي كاهل اليشكري، ديوان سويد بن أبي كاهل اليشكري، جمع وتحقيق: شاكر العاشور، مراجعة: محمد جبار

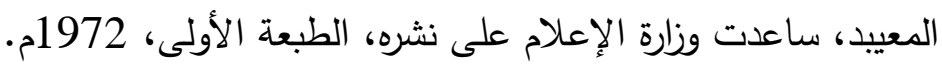
الثنفرى، عمرو بن مالك، ديوان الثنفرى، جمعه وحققه وشرحه: إيميل بديع يعقوب، دار الكتاب العربي، بيروت، الطبعة الثانية، 1417هـ-1996م.

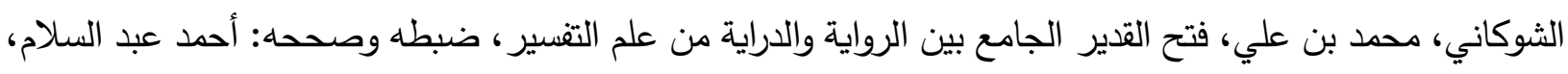
دار الكتب العلمية، بيروت-لبنان. ابن أبي شيبة، عبد الله بن محمد (المتوفى: 235هـ)، الكتاب المصنف في الأحاديث والآثار ، تحقيق: كمال يوسف الحوت، الطبعة الأولى، مكتبة الرشد - الرياض، البه، 1409 هـ. الصنعاني، عبد الرزاق بن همام (المتوفى: 211هـ)، المصنف، تحقيق: حبيب الرحمن الأعظي، الطبعة الثانية، المجلس العلمي-الهند، المكتب الإسلامي - بيروت، 1403هـ. صيام، محمد الثيخ محمود، المعتقدات والقيم في الثعر الجاهلي، رسالة دكتوراه في الآداب، كلية اللغة العربية، جامعة أم القرى، مكة المكرمة، 1402هـ-1982م. 
الضبي، مفضل بن محمد، أمثال العرب، تحقيق: حسين قصي، دار ومكتبة الهلال، بيروت-لبنان. طرفة بن العبد، ديوان طرفة بن العبد، تحقيق: مهدي محمد ناصر الدين، دار الكتب العلمية، الطبعة الثالثة، 1423هــ.2002

ابن عابدين، محمد أمين (المتوفى: 1252هـ)، حاشية رد المحتار على الدر المختار شرح تنوير الأبصار، تحقيق: عادل أحمد عبد الموجود - علي محمد معوض، عالم الكتب 1423 هـ- 2003 م. ابن قدامة المقدي، عبد الله بن أحمد (المتوفى: 620هـ)، الكافي، الطبعة الأولى، دار الكتب العلمية الطبعة، 1414 هـ - 1994 مـ

عروة بن الورد، ديوان عروة بن الورد أمير الصعاليك، دراسة وشَزْح وتحقيق: أسماء أبو بكر محمد، دار الكتب العلميّة-

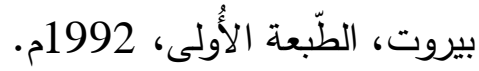
عنترة بن شداد، ديوان عنترة بن شدّاد، تحقيق: بدر الدين حاضري، دار الشّرق العربي-بيروت، الطّبعة الأولى، 1992

العيني، بدر الدين محمود بن أحمد بن موسى (المتوفى 855 هـ)، المقاصد النحوية في شرح شواهد شروح الألفية المشهور بـ اشرح الثواهد الكبرى《، تحقيق: علي محمد فاخر، أحمد محمد توفيق السوداني، عبد العزيز محمد فاخر ، دار السلام للطباعة والنشر والتوزيع والترجمة، القاهرة -جمهورية مصر العربية الطبعة: الأولى، 1431 هـ - 2010

غانم، محمد عبده، مع الثعراء في العصر العباسي، دار الفكر المعاصر ، المكتبة اليمنية للنشر والتوزيع، 2007م. ابن قدامة المقدسي، عبد الله بن أحمد (المتوفى: 620هـ)، المغني، مكتبة القاهرة، 1388هـ - 1968م. ابن ماجة، محمد بن يزيد (المتوفى: 273هـ)، سنن ابن ماجة، تحقيق: محمد فؤاد عبد الباقي، دار إحياء الكتب

الكاساني، أبو بكر بن مسعود (المتوفى: 587هـ)، بدائع الصنائع في ترتيب الثرائع، الطبعة الثانية، دار الكتب العلمية،

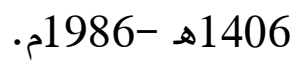
كثيرّ عزّة، ديوان كثيرّ عزّة، جمعه وشرحه: إحسان عباس، دار الثقافة-بيروت، لبنان، 1391هـ-1971م.

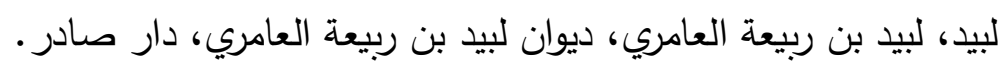

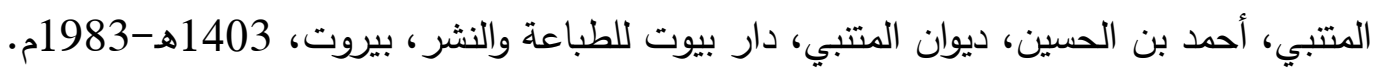
مسلم، مسلم بن الحجاج (المتوفى: 261هـ)، صحيح مسلم، تحقيق: محمد فؤاد عبد الباقي، دار إحياء التراث العربيبيروت. النابغة الجعدي، ديوان النابغة الجعدي، تحقيق: واضح الصمد، دار صادر -بيروت، الطّبعة الأولى، 1998م.

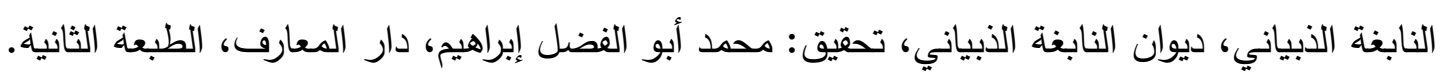


• أبو نعيم الأصبهاني، أحدد بن عبد الله (المتوفى: 430هـ)، معرفة الصحابة، تحقيق: عادل بن يوسف العزازي، الطبعة

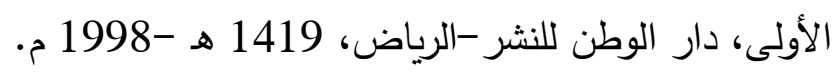

• النووي، يحي بن شرف (المتوفى: 676هـ)، روضة الطالبين وعمدة المفتين، تحقيق: زهير الثاويش، الطبعة الثالثة،

$$
\text { المكتب الإسلامي، بيروت-دمشق -عمان، 1412هـ بـ - 1991م. }
$$

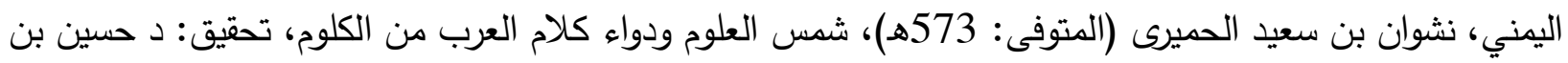

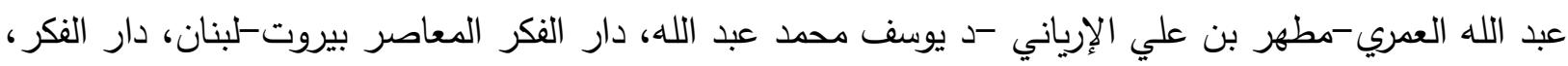

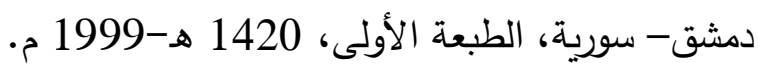

